\title{
Two new species and the molecular phylogeography of the freshwater crab genus Bottapotamon (Crustacea: Decapoda: Brachyura: Potamidae)
}

\author{
Ning Gao ${ }^{1}$, Ying-Yi Cui ${ }^{1}$, Song-Bo Wang ${ }^{1}$, Jie-Xin Zou ${ }^{\text {Corresp. } 1}$ \\ ${ }^{1}$ Research Laboratory of Freshwater Crustacean Decapoda \& Paragonimus, School of Basic Medical Sciences, Nanchang University, Nanchang, Jiangxi \\ Province, China \\ Corresponding Author: Jie-Xin Zou \\ Email address: jxzou@ncu.edu.cn
}

Bottapotamon chenzhouense sp. n. and B. luxiense sp. n. are described from Hunan Province and Jiangxi Province, respectively. These species both have diagnostic features of the genus Bottapotamon and discernible characteristics as new species. $B$. chenzhouense sp. n. can be distinguished from co - geners by features such as the $G 1$, which has a fold covering the surface of the entire subterminal article with a distal region. $B$. luxiense sp. $n$. has an elliptical carapace, and a sturdy and blunt terminal article of G1. The molecular phylogeny and biogeography of the genus Bottapotamon (Decapoda: Brachyura: Potamidae) were studied, using mitochondrial cytochrome oxidase I (mtDNA COI), 16S rRNA and nuclear histone $\mathrm{H} 3$ gene fragments. The results support the assignment of the two new species to the genus Bottapotamon. In addition, the divergence time of the genus Bottapotamon was estimated to be 3.49 - $1.08 \mathrm{Ma}$, which coincided with various vicariant and dispersal events that occurred in the geological area where the genus Bottapotamon is commonly distributed. Mountains appear to have played an important role in the distribution of this genus. The Wuyi Mountains gradually formed offshore and inland of southeastern China by the compression of the Pacific plate and the Indian plate in the Neogene - Quaternary, and the Luoxiao Mountains formed continuously in the continued forming in the north-south direction because of neotectonic movement, have resulted in the geographical distribution pattern of the genus Bottapotamon, which was also established gradually. 
1 Two new species and the molecular phylogeography of the 2 freshwater crab genus Bottapotamon (Crustacea: Decapoda: 3 Brachyura: Potamidae)

4 Ning Gao ${ }^{1}$, Ying-yi Cui ${ }^{1}$, Song-bo Wang ${ }^{1}$, Jie-xin Zou ${ }^{1}$

$5 \quad{ }^{1}$ Research Laboratory of Freshwater Crustacean Decapoda \& Paragonimus, School of Basic

6 Medical Sciences, Nanchang University, Nanchang, Jiangxi, China.

7

8 Corresponding Author:

9 Jie-xin Zou ${ }^{1}$

101299 Xuefu Avenue, Nanchang City, Jiangxi Province 330031, China

11 Email address: jxzou@ncu.edu.cn

12 


\section{Abstract}

Bottapotamon chenzhouense sp. n. and B. luxiense sp. n. are described from Hunan Province and Jiangxi Province, respectively. These species both have diagnostic features of the genus Bottapotamon and discernible characteristics as new species. B. chenzhouense sp. n. can be distinguished from co - geners by features such as the G1, which has a fold covering the surface of the entire subterminal article with a distal region. B. luxiense sp. $\mathrm{n}$. has an elliptical carapace, and a sturdy and blunt terminal article of G1. The molecular phylogeny and biogeography of the genus Bottapotamon (Decapoda: Brachyura: Potamidae) were studied, using mitochondrial cytochrome oxidase I (mtDNA COI), 16S rRNA and nuclear histone H3 gene fragments. The results support the assignment of the two new species to the genus Bottapotamon. In addition, the divergence time of the genus Bottapotamon was estimated to be $3.49-1.08 \mathrm{Ma}$, which coincided with various vicariant and dispersal events that occurred in the geological area where the genus Bottapotamon is commonly distributed. Mountains appear to have played an important role in the distribution of this genus. The Wuyi Mountains gradually formed offshore and inland of southeastern China by the compression of the Pacific plate and the Indian plate in the Neogene - Quaternary, and the Luoxiao Mountains formed continuously in the continued forming in the north-south direction because of neotectonic movement, have resulted in the geographical distribution pattern of the genus Bottapotamon, which was also established gradually.

\section{Introduction}

The genus Bottapotamon is a unique genus of freshwater crabs from the China mainland. In 55 1997, three species of the genus Malayopotamonon (Bott, 1967; Cheng et al., 1993; Dai et al., 56 1979) and one new species were identified as Bottapotamon on the basis of its morphological 57 characteristics, such as the form of carapace and first gonopod (G1) (Türkay \& Dai, 1997). Until 
58

59

60

61

62

63

64

65

66

67

68

69

70

71

72

73

74

75

76

77

78

79

80

81

82

83

84

85

86

87

88

89

90

91

92

93

94

95

96

97

98

99

the current study, the genus Bottapotamon contained B. fukiense (Dai et al., 1979), B. engelhardti (Bott, 1967), B. yonganense (Cheng et al., 1993), B. lingchuanense (Türkay \& Dai, 1997), $B$. youxiense (Cheng et al., 2010) and B. nanan (Zhou et al., 2008).

The relatively low fecundity and poor dispersal abilities of freshwater crabs (Daniels et al., 2003; Yeo et al., 2008) mean that these crabs are easily isolated by barriers such as mountains or seas. Geographically isolated populations then become genetically natural distinct and result in allopatric speciation (Shih et al., 2006; Yeo et al., 2007). In mainland China, the distribution of the genus Bottapotamon is restricted within the area of the Wuyi Mountain Range; $B$. engelhardti, B. yonganense, $B$. youxiense and $B$. nanan are distributed east of the Wuyi Mountain Range, B. fukiense occurs on both sides of the Wuyi Mountains (Fujian and Jiangxi Provinces), and only B. lingchuanense has been isolated in the Nanling Mountain Range (Dai, 1997) (Fig. 1). The geographic barrier separating the Wuyi Mountains from the Nanling Mountains is the Luoxiao Mountain Range, which is the highest range in the area, exceeding $2120 \mathrm{~m}$ in height (Gong et al., 2016). The terrain the genus Bottapotamon now inhabits is geologically relatively stable and experienced little orogenic activity during the Cenozoic Era (Yi, 1996; Zhou \& Li, 2000). Therefore, we hypothesize that the current distribution of the genus Bottapotamon in mainland China was caused by the emergence of these mountains.

While organizing the existing specimens deposited at the Department of Parasitology of the Medical College of Nanchang University (NCU MCP) and the newly collected specimens, the first and third author discovered two new species collected from Chenzhou City, Hunan Province, and Luxi County, Jiangxi Province, respectively. This paper compares the morphological features of eight species including two new species of the genus Bottapotamon, as well as 16S rRNA (Crandall et al., 1996), mtDNA COI (Folmer et al., 1994) and nuclear histone H3 (Colgan et al., 1998) gene fragments that are uesd to support the establishment of new species in the genus Bottapotamon. The phylogenetic relationship, distribution pattern and possible association with major geological and historical events are also discussed.

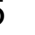

\section{Materials \& Methods}

\section{Specimens collection}

Specimens from Jiangxi, Zhejiang, Fujian and Guangxi, were recently collected and preserved in $95 \%$ ethanol. The remaining specimens used in this study were from and deposited at the Department of Parasitology of the Medical College of Nanchang University (NCU MCP), Jiangxi Province, China. The authors compared specimens with holotypes of the National Zoological Museum of China, Chinese Academy of Sciences (CAS). All 26 specimens were used for mtDNA COI, 16S rRNA and histone $\mathrm{H} 3$ gene fragment amplification (Table 1).

\section{Phylogenetic analyses and Divergence time estimation}

Genomic DNA was extracted from leg muscle tissue with an OMEGA EZNA ${ }^{\mathrm{TM}}$ Mollusc DNA Kit. The 16S rRNA, mtDNA COI, and histone $\mathrm{H} 3$ regions were selected for amplification by polymerase chain reaction (PCR) (Table 2). The amplification products were sent to the Beijing Genomics Institute for bidirectional sequencing, and the sequencing results were spliced manually to obtain the sequence data. DNA sequences of $B$. yonganense specimens collected 
100 from the suburb of Sanming City, Fujian Province, China, could not be amplified due to poor 101 preservation.

102 The sequences of four individuals with the same primer sequences were selected from 103 National Center for Biotechnology Information (NCBI) database, as the outgroups 104 (Candidiopotamon rathbunae (GenBank accession numbers: mtDNA COI - AB290649, 16S 105 rRNA - AB208609, histone H3 - AB290668), Geothelphusa dehaani (GenBank accession 106 numbers: mtDNA COI - AB290648, 16S rRNA - AB290630, histone H3 - AB290667), 107 Himalayapotamon atkinsonianum (GenBank accession numbers: mtDNA COI - AB290651, 16S 108 rRNA - AB290632, histone H3 - AB290670), and Ryukyum yaeyamense (GenBank accession

109

110

111

112

113

114

115

116

117

118

119

120

121

122

123

124

125

126

127

128

129

130

131

132

133

134

135

136

137

138

139 numbers: mtDNA COI - AB290650, 16S rRNA - AB290631, histone H3 - AB290669). After comparing and selecting the conservative regions, each sequence was $1323 \mathrm{bp}$ in length. According to the Akaike information criterion (AIC), MrMTGui: ModelTest and MrModelTest (phylogenetic analysis using parsimony (PAUP)) determined the best models was GTR $+\mathrm{I}+\mathrm{G}$; MEGA 6.06 (Tamura et al., 2013) was used to establish a phylogenetic tree based on the maximum likelihood (ML) (Trifinopoulos et al., 2016). The Bayesian inference (BI) tree was established using MrBayes (Ronquist \& Huelsenbeck 2003).

The divergence times of genus Bottapotamon were estimated from the combined 16S rRNA and mtDNA COI sequences, based on the Bayesian evolutionary analysis sampling trees (BEAST) program, and four calibration points were used. The Potamidae family has been divided into two major subfamilies, Potamiscinae and Potaminae, estimated to have a divergence time of 20.9 - 24.7 Ma, which was set as calibration point 1 in our study (Shih et al., 2010). From the Parathelphusidae subfamily, Somanniathelphusa taiwanensis, which is distributed in Taiwan Island and separated from Somanniathelphusa amoyensis, which is distributed in Fujian Province, for approximately $0.27-1.53 \mathrm{Ma}$ (Jia et al., 2018). This is consistent with the quaternary glacial period and interglacial period and agrees with the separation of Taiwan Island and Fujian Province; this time point was set as calibration point 2. In the geological area where genus Bottapotamon is distributed, the Wuyi Mountains gradually formed by the compression of the Pacific plate and the Indian plate in the Neogene-Quaternary (1.64 - 23.3 Ma) (Li, 1984); this time point was set as calibration point 3. A Yule speciation model was constructed for speciation within the genus Bottapotamon. We used a GTR $+\mathrm{G}$ model with parameters obtained from MrMTGui: ModelTest and MrModelTest (PAUP) for each gene. Seventeen independent MCMC chains were run for 200,000,000 generations, and every 20,000 generations were sampled. The convergence of the 17 combined chains was determined by the evolutionary stable strategy (ESS) (>200 as recommended) for each parameter in Tracer after the appropriate burn-in and cutoff (default of $10 \%$ of sampled trees). Trees in the 17 chains were combined using LogCombiner (v.1.6.1, distributed as part of the BEAST package) and were assessed using TreeAnnotator (v.1.6.1, distributed as part of the BEAST package). A chronogram was constructed by FigTree.

\section{Nomenclatural note}


140

141

142

143

144

145

146

147

148

149

150

151

152

153

154

155

156

157

158

159

160

161

162

163

164

165

166

167

168

169

170

171

172

173

174

175

176

177

178

The electronic version of this article in Portable Document Format (PDF) will represent a published work according to the International Commission on Zoological Nomenclature (ICZN), and hence the new names contained in the electronic version are effectively published under that Code from the electronic edition alone. This published work and the nomenclatural acts it contains have been registered in ZooBank, the online registration system for the ICZN. The ZooBank LSIDs (Life Science Identifiers) can be resolved and the associated information viewed through any standard web browser by appending the LSID to the prefix http://zoobank.org/. The LSID for this publication is: [urn: 1sid: zoobank.org: pub:211926FF-6950-4DFE-95C4F5247CA9E0BA]. The online version of this work is archived and available from the following digital repositories: Peer J, PubMed Central and CLOCKSS.

\section{Results}

\section{Systematics}

Potamidae Ortmann, 1896

Bottapotamon Tüerkay \& Dai, 1997

Bottapotamon chenzhouense sp. n. Gao, Cui \& Zou (Figs. 2-6)

urn: 1sid zoobank. org: art: E43C4BBB-E429-4C17-8ACD-E4295F426BCB

\section{Materials examined}

Holotype: 1 ภ $(20.67 \times 15.60 \mathrm{~mm})(\mathrm{NCU}$ MCP 643), Huangcao Village, Chenzhou City, Hunan Province, China, 2539'24.60"N, 11330'4.07"E, 141 m asl. Coll. Ding-mei Luo, July $26^{\text {th }}, 2006$. Paratypes: 1 $9(18.64 \times 14.62 \mathrm{~mm})(\mathrm{NCU}$ MCP 643), the same data as the holotype.

\section{Comparative materials}

B. fukiense (Dai et al., 1979): 2 đ (15.66 × $12.64 \mathrm{~mm}, 13.15 \times 10.26 \mathrm{~mm})(\mathrm{NCU} \mathrm{MCP}$ 4089), Xiapu Village, Ningde County, Fujian Province; $1 \lesssim(13.26 \times 11.05 \mathrm{~mm})(\mathrm{NCU} \mathrm{MCP}$ 4156), Shangshan Village, Zhenghe County, Fujian Province; 1 § $(22.93 \times 17.67 \mathrm{~mm})(\mathrm{NCU}$ MCP 4090), Siqian Village, Shouning County, Fujian Province; 1 ( $(19.26 \times 15.70 \mathrm{~mm})(\mathrm{NCU}$ MCP 4090), Shangshan Village, Zhenghe County, Fujian Province. B. engelhardti (Bott, 1967): 3 ठิ ภે $(15.32 \times 11.90 \mathrm{~mm}, 17.08 \times 13.46 \mathrm{~mm}, 18.85 \times 15.01 \mathrm{~mm})(\mathrm{NCU}$ MCP 4157), Tangsan Village, Youxi County, Fujian; 3 ภึ कึ $(16.23 \times 13.78 \mathrm{~mm}, 17.50 \times 14.41 \mathrm{~mm}, 14.86 \times 11.18 \mathrm{~mm})$ (NCU MCP 4091), Chimu Village, Youxi County, Fujian Province; 1 + $(28.03 \times 21.97 \mathrm{~mm})$ (NCU MCP 4091), Chimu Village, Youxi County, Fujian Province. B. yonganense (Cheng et al., 1993): 1 đ (22.97 × $18.19 \mathrm{~mm})(\mathrm{NCU}$ MCP 4096), Sanming City, Fujian; B. lingchuanense

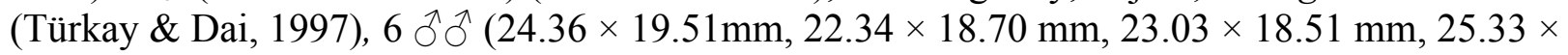
$19.46 \mathrm{~mm}, 24.92 \times 19.10 \mathrm{~mm}, 18.04 \times 14.41 \mathrm{~mm})(\mathrm{NCU}$ MCP 4076), Yuanpu Village, Gongcheng County, Guangxi Zhuang Autonomous Region; 4 के के $(19.36 \times 15.55,19.56 \times 15.69 \mathrm{~mm}, 19.68 \times$ 
179

180

181

182

183

184

185

186

187

188

189

190

191

192

193

194

195

196

197

198

199

200

201

202

203

204

205

206

207

208

209

210

211

212

213

214

215

216

217

218

219

16.15mm, $20.11 \times 15.98 \mathrm{~mm})($ NCU MCP 3281), Bindong Village, Lingchuan County, Guangxi Zhuang Autonomous Region; 3 우 $(20.94 \times 16.27 \mathrm{~mm}, 19.87 \times 16.29 \mathrm{~mm}, 22.19 \times 17.73 \mathrm{~mm}$, $20.22 \times 15.97 \mathrm{~mm}$ ), (NCU MCP 3281), Bindong Village, Lingchuan County, Guangxi Zhuang Autonomous Region. B. youxiense (Cheng et al., 2010): 4 ô $\sigma^{\lambda}(14.27 \times 12.21 \mathrm{~mm}, 13.57 \times 11.05$ $\mathrm{mm}, 13.78 \times 11.16 \mathrm{~mm}, 14.09 \times 11.42 \mathrm{~mm})(\mathrm{NCU}$ MCP 4092), 2 ○ $(13.35 \times 10.60 \mathrm{~mm}, 13.41 \times$ $11.02 \mathrm{~mm})(\mathrm{NCU}$ MCP 4158) . B. nanan (Zhou et al., 2008): 2 § $(28.48 \times 22.65 \mathrm{~mm}, 22.23 \times$

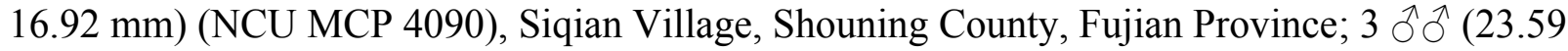
$\times 18.92 \mathrm{~mm}, 21.73 \times 17.36 \mathrm{~mm}, 22.98 \times 17.38 \mathrm{~mm})(\mathrm{NCU}$ MCP 4038), Yongjia County, Zhejiang Province; $2 \widehat{\delta}(17.49 \times 13.60 \mathrm{~mm}, 21.28 \times 16.11 \mathrm{~mm})$, Yongjia County, Zhejiang Province; $1 q(20.01 \times 15.01 \mathrm{~mm})(\mathrm{NCU}$ MCP 4039), Yongjia County, Zhejiang Province.

\section{Diagnosis}

Carapace subquadrate, flat, dorsal surface smooth (Fig. 2); approximately about 1.3 times broader than long; third maxilliped ischium about 1.5 times as long as broad, exopod without flagellum (Fig. 3A); male pleon triangular, sixth somite width 2.5 times length; telson triangular, tip rounded, with proximal width 1.7 times length; median groove of male thoracic sternum deep, interruption between sutures of sternites 4/5, 5/6, 6/7 broad (Fig. 4). G1 long, tip of terminal segment reaching beyond suture between thoracic sternites $4 / 5$ in situ; subterminal segment 1.3 times as long as terminal segment; terminal segment slightly elongated, curved inward, distal part of terminal segment elongated with anterioventrally directed semicircular lobe. Female vulvae partially exposed anteriorly to the thoracic sternites $5 / 6$ in situ, ovate, deep, posteromesial margin with a low raised rim, opened inward.

\section{Description}

Carapace approximately about 1.3 times broader than long, dorsal surface gently convex from frontal view, regions not prominently inflated; with surface slightly pitted. Cervical groove shallow, indistinct. H-shaped groove between the gastric region and cardiac region shallow but distinct. Postfrontal lobe blunt, separated medially by a Y-shaped groove extending to frontal region; postorbital crest indistinct, postorbital region slight concave. Frontal region deflexed downwards. Dorsal orbital margin ridged, external orbital angle triangular outer margin smooth; Anterolateral margin cristate, epibranchial tooth pointed, indistinct, clearly demarcated from external orbital tooth (Fig. 2).

Third maxilliped merus about 1.3 times as broad as long; Ischium about 1.5 times as long as broad, with distinct median sulcus; exopod reaching proximal third of merus length, without flagellum (Fig. 3A).

Male sternum pitted, sternites 1, 2 fused to form triangular structure; sternites 2, 3 separated by continuous suture; boundary between sternites ,3, 4 present. Male sterno-pleonal cavity broad, shallow, with narrow median interruption in sutures $4 / 5,5 / 6,6 / 7$; median line between sternites 7, 8 moderately short; male pleonal locking tubercle on posterior third of sternite 5 (Fig. 4).

Cheliped slightly unequal; margins crenulated; carpus with sharp spine on inner distal angle, with spinule at base; outer surface of manus with convex granules, manus about 1.6 times

Peer] reviewing PDF | (2019:04:36419:4:0:NEW 30 Sep 2019) 
220

221

222

223

224

225

226

227

228

229

230

231

232

233

234

235

236

237

238

239

240

241

242

243

244

245

246

247

248

249

250

251

252

253

254

255

256

257

258

259

as long as high, slightly longer than movable finger, gape wide when fingers closed, cutting edge lined with low teeth (Fig. 3C).

Ambulatory legs slender; margins of propodus smooth; last leg with propodus about 1.8 times as long as broad, slightly shorter than dactylus (Fig. 3B).

G1 slender, ventral flap with transparent protrusion, with a fold covering the surface of theentire subterminal. Tip of terminal segment slightly reaching beyond sternal pleonal locking structure in situ, subterminal segment about 1.3 times as long as terminal segment. G1 slightly curved anterioventrally; distal part of G1 terminal segment distinctly broader than proximal part. G2 subterminal segment about 2.3 times as long as terminal segment (Figs. 5A and 6A).

\section{Remarks}

The new species fits well within the morphological definition of the genus Bottapotamon (Türkay \& Dai, 1997; Cheng et al., 2010; Zhou et al., 2008): G1 is slender, tip of terminal segment reaching suture between thoracic sternites $4 / 5$ in situ; terminal segment slightly elongated inward (Table. 3). Nonetheless, the new species can be distinguished from co - genus, by the carapace surface gently convex, cervical groove indistinct; H-shaped groove shallow but distinct; epibranchial tooth pointed and indistinct, third maxilliped without flagellum; chelipeds carpus with sharp spine on inner distal angle; and the ventromedially curved G1, which subterminal segment about 1.3 times as long as terminal segment (Table. 3). The most obvious specific character of the new species is that the ventral flap of G1 with transparent protrusion, with a fold covering the surface of the entire subterminal region (Figs. $5 \mathrm{~A}$ and $6 \mathrm{~A}$ ).

\section{Etymology}

The species is named after the type locality: Chenzhou city, Hunan Province, China.

\section{Distribution}

B. chenzhouense sp. n. was found under stones in a mountain stream in Huangcao village, Sunxian District, Chenzhou City, Hunan Province, China.

Bottapotamon luxiense sp. n. Gao, Cui \& Zou (Figs. 5-10)

urn: 1sid zoobank. org: art: 1C1CC520-193A-405E-9A2D-DC79E7D4AA87.

\section{Materials examined}

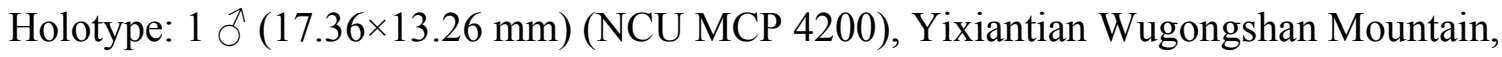

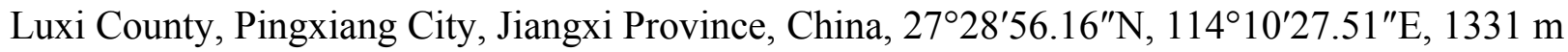
asl. Coll. Song-bo Wang, May 6 ${ }^{\text {th }}$, 2019. Paratypes: $1 \overbrace{}^{\Uparrow}(19.21 \times 14.67 \mathrm{~mm})(\mathrm{NCU}$ MCP 4200). Others: 10 우 $(17.51 \times 13.89 \mathrm{~mm}, 14.43 \times 11.30 \mathrm{~mm}, 17.93 \times 14.23 \mathrm{~mm}, 18.08 \times 14.39 \mathrm{~mm}$, $19.61 \times 15.58 \mathrm{~mm}, 16.77 \times 12.74 \mathrm{~mm}, 15.88 \times 12.00 \mathrm{~mm}, 17.40 \times 13.77 \mathrm{~mm}, 16.36 \times 12.93$

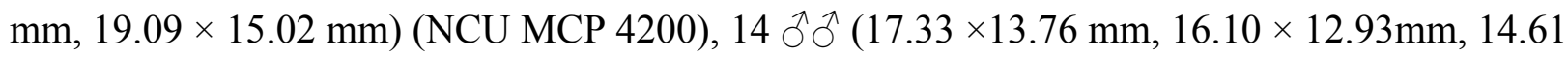
$\times 12.10 \mathrm{~mm}, 15.03 \times 11.27 \mathrm{~mm}, 12.01 \times 9.24 \mathrm{~mm}, 12.01 \times 9.48 \mathrm{~mm}, 10.59 \times 8.33 \mathrm{~mm}, 12.61 \times$ 
260

261

262

263 Comparative materials

264 Same as Bottapotamon chenzhouense sp. n.

265

266

267

268

269

270

271

272

273

274

275

276

277

278

279

280

281

282

283

284

285

286

287

288

289

290

291

292

293

294

295

296

297

298

299

300

\section{Diagnosis} inward.

\section{Description} pointed (Fig. 7). length, with flagellum (Fig. 8A). lined with low teeth (Fig. 8B).

$10.39 \mathrm{~mm}, 13.53 \times 10.89 \mathrm{~mm}, 14.12 \times 11.24 \mathrm{~mm}, 12.84 \times 10.07 \mathrm{~mm}, 12.15 \times 9.76 \mathrm{~mm}, 14.31 \times$ $11.64 \mathrm{~mm}, 11.71 \times 9.20 \mathrm{~mm})(\mathrm{NCU} \mathrm{MCP} 4200)$, the same data as holotype.

Carapace about 1.3 times broader than long, subquadrate, flat, dorsal surface gently convex longitudinally; cervical groove distinct, $\mathrm{H}$-shaped groove between gastric, cardiac regions distinct (Fig. 7); third maxilliped ischium about 1.5 times as long as broad, with flagellum (Fig. $8 A$ ); male abdomen broadly triangular, telson triangular, with about 1.6 times as broad as long(Fig. 6B); median groove of male thoracic sternum deep, interruption between sutures of sternites $4 / 5,5 / 6,6 / 7$ broad. G1 long and blunt, tip of terminal segment reaching suture between thoracic sternites $4 / 5$ in situ; subterminal segment 1.2 times as long as terminal segment; terminal segment slightly elongated inward, distal part of terminal segment elongated with anterioventrally directed semicircular lobe. Female vulvae partially exposed anteriorly to the thoracic sternites 5/6 in situ, ovate, deep, posteromesial margin with a low raised rim, opened

Carapace nearly ellipse in shape, about 1.3 times broader than long, flat, dorsal surface punctate, glabrous; regions distinctly defined; epibranchial region rugose, mesogastric

regionslightly convex. Cervical groove distinct. H-shaped groove between the gastric region and cardiac region shallow but distinct. Postfrontal lobe blunt; postorbital crest indistinct, postorbital region slight concave. Frontal region deflexed downwards. Dorsal orbital margin ridge, external orbital angle triangular, outer margin smooth. Anterolateral margin cristate, epibranchial tooth

Third maxilliped merus trapezoidal about 1.4 times as broad as long; ischium about 1.5 times as long as broad, with distinct median sulcus; exopod reaching proximal third of merus

Thoracic sternum pitted; sternites $1 / 2$ completely fused to form triangular structure; sternites $2 / 3$ separated by continuous suture; boundary between sternites $3 / 4$ present, indistinct. Sterno-pleonal cavity broad, shallow, with narrow median interruption in sutures $4 / 5,5 / 6,6 / 7$; median line between sternites $7 / 8$ moderately long (Fig. 9).

The male sternum is relatively flat with numerous small pits; sternites $1 / 2$ fused triangular; transverse sulcus between sternites $2 / 3$ suture; sternites $3 / 4$ fused without obvious demarcation. Male sterno-pleonal cavity is medium in depth wide; median longitudinal groove between sternites $7 / 8$ short; male pleonal locking tubercle on posterior third of sternite 5 (Fig. $6 \mathrm{~B}$ ).

Chelipeds slightly unequal; outer surface of manus with granules, manus about 1.5 times as long as high, slightly longer than movable finger, gape wide when fingers closed, cutting edge 
301

302

303

304

305

306

307

308

309

310

311

312

313

314

315

316

317

318

319

320

321

322

323

324

325

326

327

328

329

330

331

332

333

334

335

336

337

338

339

340

341

342

Ambulatory legs slender; margins of propodus smooth; last leg with propodus about 1.7 times as long as broad, slightly shorter than dactylus (Fig. 8C).

G1 blunt, tip of terminal segment slightly reaching beyond sternal pleonal locking structure in situ, subterminal segment about 1.4 times as long as terminal segment. G1 slightly curved ventrolaterally; distal part of G1 terminal segment distinctly broader than proximal part. G2 subterminal segment about 2.2 times as long as terminal segment (Figs. 5B and 6B).

\section{Remarks}

The new species fits well within the morphological definition of the genus Bottapotamon (Türkay \& Dai, 1997; Cheng et al., 2010; Zhou et al., 2008), especially similar to B. fukiense, and $B$. lingchuanense in shape of carapace and slender G1. With regards to the other species of genus Bottapotamon, they can be separated (Table. 3). Adult male specimens of B. luxiense sp. $\mathrm{n}$. have the gastric regions relatively smooth with the rest of the surfaces also some rugose and granulose; H-shaped groove shallow but distinct (Fig. 7). The G1 of B. luxiense sp. n. is also quite dfferent with the terminal segment straight, slender and blunting towards the tip (Figs. $5 B$ and $6 B$ ); third maxilliped with flagellum; median longitudinal groove between sternites $7 / 8$ short; chelipeds carpus with sharp spine on inner distal angle, with spines at base(Fig. 8B).

\section{Etymology}

The species is named after the type locality: Yixiantian Wugongshan Mountain, Luxi County, Pingxiang City, Jiangxi Province, China.

\section{Living coloration}

The dorsal surfaces of the carapace and pereopods are dark purple-red, and the joints of the cheliped merus and carpus the ambulatory legs are bright red. The inner surface of the immovable finger and distal part of the movable finger are almost milky.

\section{Distribution}

B.luxiense sp. n. was found under stones in a mountain stream in Yixiantian Wugongshan Mountain, Luxi County, Pingxiang City, Jiangxi Province, China (Fig. 10).

\section{Ecology}

B. chenzhouense sp. n. and B. luxiense sp. n. were collected in the Luoxiao mountains. This region has a humid subtropical monsoon climate and is in the Xiangjiang River and Ganjiang River watershed, which has rich biodiversity (Wang, 1998). Similar to the natural habitat of other Bottapotamon species, B. chenzhouense sp. n. and B. luxiense sp. n. can be found under small rocks in sandy creek beds in narrow mountain streams or highway drains with clear, slow flowing and cool water surrounded by dwarf shrubs or grasses (Fig. 10).

\section{Phylogenetic analyses and Divergence time estimation}

Within genus Bottapotamon, a 1323 bp segment (excluding the primer regions) of the combined mtDNA COI, 16S rRNA and nuclear histone H3 from all 25 specimens was analysed. 
343 The phylogenetic trees were constructed by ML analysis, and the corresponding support values

344 were calculated by ML and BI analyses, both of which had high support values. The results

345 showed that the genus Bottapotamon is monophyletic, and confirmed that B. chenzhouense sp. $\mathrm{n}$.

346 and B. luxiense sp. n. are new species of genus Bottapotamon and supported the relationship of

347 the genus Bottapotamon (Fig. 11). With regard to the relationships among the all specimens,

348 the phylogenetic tree also show some distinct geographical distibution (Fig. 1). B. engelhardti, B.

349 yonganense and $B$. nanan, which are mostly distributed in the Wuyi Mountain Range, form a

350 clade; $B$. luxiense sp. n. forms a sister clade to the clade of $B$. engelhardti, $B$. yonganense and $B$.

351 nanan. The next sister clade is composed of $B$. chenzhouense sp. n., which is distributed in the

352 Luoxiao Mountain Range, and the furthest sister clade is composed of B. lingchuanense, which

353 is situated some diatance from the Wuyi Mountain Rnage and Luoxiao Mountain Range, but

354 near the Nanling Mountain. However, B. fukiense and B. youxiense are also distributed in the

355 Wuyi Mountain Range, they do not assemble with B. engelhardti, B. yonganense and B. nanan.

356 Based on the relaxed molecular clock estimation, the earliest divergence time for genus

357

358

359

360

361

362

363

364

365

366

367

368

369

370

371

372

373

374

375

376

377

378

379

380

381

382

Bottapotamon was estimated to be $3.49-1.08 \mathrm{Ma}$. The divergence time estimation results are consistent with the four calibration points. B. fukiense and B. youxiense diverged $1.96 \mathrm{Ma}(95 \%$ confidence interval $=2.65-1.31 \mathrm{Ma}), B$. luxiense diverged $1.90 \mathrm{Ma}(95 \%$ confidence interval $=2.05-1.09 \mathrm{Ma}), B$. lingchuanense and $B$. chenzhouense sp. n. diverged $1.51 \mathrm{Ma}(95 \%$ confidence interval $=1.6-0.7 \mathrm{Ma}) ; B$. engelhardti and B. nanan diverged $1.08 \mathrm{Ma}(95 \%$ confidence interval $=1.76-0.80 \mathrm{Ma})$ (Fig. 12).

\section{Discussion}

In mainland China, the genus Bottapotamon is primarily distributed in the Wuyi Mountain Range area; B. luxiense sp. n., B. youxiense, B. nanan, B. engelhardti and B. yonganense are restricted within an area east of the Wuyi Mountain Range (Fig. 1). There is no record of any of these five species in Jiangxi, despite extensive surveys of this area by the authors and their colleagues over many years (Dai, 1999; Shi, 2012). The altitude of the Wuyi Mountain Range is clearly high enough to prevent these species from reaching Jiangxi. B. fukiense occurs on both sides of the Wuyi Mountain Range (Fujian and Jiangxi Provinces), and is able to disperse across these mountains. The divergence time of $B$. fukiense is $1.96 \mathrm{Ma}(95 \%$ confidence interval $=2.65$ - $1.31 \mathrm{Ma}$ ) (Fig. 12), and the divergence time agrees well with records of the Pacific plate and Indian plate extrusion in the Neogene-Quaternary (1.64 - 23.3 Ma) (Li, 1984). Therefore, these geological events may explain the distribution pattern of the genus Bottapotamon in the Wuyi Mountain Range. The ancestor of B. fukiense originated in an area close to the Wuyi Mountains, which probably dispersed across the Wuyi Mountain Range when it was still a lowland, before the Wuyi Mountain Formation and smaller-scale mountain deformations occured and separated.

In the Nanling mountain range, unique karst formation and the south Asian subtropical humid monsoon climate conditions provide a good living environment for all types of wildlife, including freshwater crabs. However, only one species of the genus Bottapotamon, $B$.

Peer] reviewing PDF | (2019:04:36419:4:0:NEW 30 Sep 2019) 
383 lingchuanense, was isolated in this area, and there is an $830 \mathrm{~km}$ gap between $B$. lingchuanense 384 and other species distributed within the Wuyi Mountain Range (Fig. 1), which has always been 385 the focus of researches on the genus Bottapotamon. This study reports two new species of genus 386 Bottapotamon, B. chenzhouense sp. n., which was first discovered in Chenzhou City, Hunan 387 Province, in south of Luoxiao Mountains, and B.luxiense sp. n., which is distributed in north of 388 the Luoxiao Mountains (Fig. 1). Divergence time estimation results suggested that $B$.

389 chenzhouense sp. n., $B$. luxiense sp. n., and $B$. lingchuanense were isolated at almost the same 390 time (B. luxiense sp. n. diverged $1.90 \mathrm{Ma}$, and B. lingchuanense and B. chenzhouense sp. $\mathrm{n}$.

391

392

393

394

395

396

397

398

399

400

401

402

403

404

405

406

407

408

409

410

411

412

413

414

415

416

417 diverged at $1.51 \mathrm{Ma}$ ) (Fig. 12). The authors speculated that the Luoxiao Mountains continuously rose due to neotectonic movement and gradually formed the Xiangjiang River and Ganjiang River watershed (Wang, 1998). The ancestors of the genus Bottapotamon occurred on both sides of the Luoxiao Mountains during the mountains formation process, and under the influence of karst landforms and the Danxia landform, gradually isolated B. luxiense sp. n., B. chenzhouense sp. $\mathrm{n}$. and B. lingchuanense. In addition, the climatic conditions in this area are ideal for Bottapotamon. The authors speculate that many new species of the genus Bottapotamon are likely to exist in the region from the Wuyi Mountain Ranges to the Nanling Mountain Range, but get to be discovered.

\section{Conclusions}

Bottapotamon chenzhouense sp. $\mathrm{n}$. and B. luxiense sp. n., two new species from the Luoxiao Mountains were reported in this paper. These two new species compensated for the geographical gap in the genus Bottapotamon, and confirm the independence and intra- and interspecific relationships of genus Bottapotamon. Combined with estimates of divergence times, this paper suggests that the genus Bottapotamon was formed at 3.49 - 1.08 Ma. Molecular evidence further supports the scientific hypothesis of the authors that genus Bottapotamon originated on both sides of the Wuyi Mountains and Luoxiao Mountains. In the geological area where the genus Bottapotamon is distributed, the Wuyi Mountains gradually formed offshore and inland of southeastern China by the compression of the Pacific plate and the Indian plate in the NeogeneQuaternary, and the Luoxiao Mountains formed continuously in the north-south direction because of neotectonic movement. Thus, the geographical distribution patterns of the genus Bottapotamon was formed gradually with the various events.

\section{Acknowledgements}


418

419

420

421

422

423

424

425

426

427

428

429

430

431

432

433

434

435

436

437

438

439

440

441

442

443

444

445

446

447

448

449

450

451

We thank Mao-rong Cai, Yi-yang Xu, Yu-Jie Zhao and Hua Guo for collecting the specimens of the new species. Special thanks are expressed to Xin-nan Jia and Shu-xin Xu for their help and advice on the manuscript. We would also like to thank Professor Xian-min Zhou for his guidance in this study.

\section{Data Availability}

Regarding data availability: all specimens in this study are housed in the permanent collections at the Department of Parasitology, Medical College of Nanchang University (NCU $\mathrm{MCP}$ ), and the raw DNA data are included in the supplemental files.

\section{REFERENCES}

Bott R. 1967. Potamoniden aus Ost-Asien (Parapotamon de Man, Sinopotamon n. gen. Candidiopotamon n. gen., Geothelphusa Stimpson) (Crustacea, Decapoda). Senckenbergiana Biologica. Frankfurt 48(3): 203-220, pls. 7-10, Figs. 1-13.

Cheng YZ, Lin GH, Li YS. 2010. Two new species of freshwater crabs (Decapoda: Potamidae) Serving as intermediate hosts of Paragonimus in Fujian, China. Chinese Journal of Parasitology and Parasitic Diseases 28: 241-245.

Cheng YZ, Lin JX, Luo XQ. 1993. A new species of crab of the genus Malayopotamon (Decapoda: Isolapotamidae). Acta Zootaxonomica Sinica 18(4): 412-416.

Colgan DJ, Mclauchlan A, Wilson GDF, Livingston SP, Edgecombe GD, Macaranas J, Cassis G, Gray MR. 1998. Histone H3 and U2 snRNA DNA sequences and arthropod molecular evolution. Australian Journal of Zoology 46: 419-437.

Crandall KA, Fitzpatrick JF, Faith D. 1996. Crayfish molecular systematics: Using a combination of procedures to estimate phylogeny. Systematic Biology 45: 1-26.

Dai AY. 1999. Fauna sinica: arthropoda crustacea malacostraca decapoda parathelphusidae potamidae. Beijing: Science Press [in Chinese with English summary].

Dai AY, Chen GX, Song YZ, Fan PF, Lin YG, Zeng YQ. 1979. On new species of freshwater crabs harbouring metacercariae of lung flukes. Acta Zootaxonomica Sinica 4(2): 122-121, $1 \mathrm{pI}$.

Daniels SR, Gouws G, Stewart BA, Coke M. 2003. Molecular and morphometric data demonstrate the presence of cryptic lineages among freshwater crabs (Decapoda: Potamonautidae: Potamonautes) from the Drakensberg Mountains, South Africa. Biological Journal of the Linnean Society 78: 129-147. 
452

453

454

455

456

457

458

459

460

461

462

463

464

465

466

467

468

469

470

471

472

473

474

475

476

477

478

479

480

481

482

483

484

485

486

487

488

489

Folmer O, Black M, Hoeh W, Lutz R, Vrijenhoek R. 1994. DNA primers for amplification of mitochondrial cytochrome c oxidase subunit I from diverse metazoan invertebrates. Molecular Marine Biology And Biotechnology 3: 294-299.

Gong HL, Zhuang WY, Liao WB. 2016. Comprehensive scientific investigation of biodiversity in Luojing Mountain area. Chinese scientific and technological achievements 7(22): 9-10.

Jia XN, Xu SX, Bai J, Wang YF, Nie ZH, Zhu CC, Wang Y, Cai YX, Zou JX, Zhou XM. 2018. The complete mitochondrial genome of Somanniathelphusa boyangensis and phylogenetic analysis of Genus Somanniathelphusa (Crustacea: Decapoda: Parathelphusidae). Plos One 13 (2): e0192601-.

Li ZZ. 1984. The origin and morphological characteristics of the Wuyi Mountain, Fujian Province. Journal of Nanjing University (Natural Sciences) [in Chinese with English summary].

Ronquist F, Huelsenbeck JP. 2003. MrBayes 3: Bayesian phylogenetic inference under mixed models. Bioinformatics 19: 1572-1574.

Shi LB, Zhang XY, Zou JX, Wang Y, Li DR, Zhu CC, Zhou XM. 2012. Distribution pattern of the freshwater crabs among Wuyi Mountains. Journal of Nanchang University (Natural Science) 36: 556-561 [in Chinese with English summary].

Shih HT, Hung HC, Schubart CD, Chen CA, Chang HW. 2006. Intraspecific genetic diversity of the endemic freshwater crab Candidiopotamon rathbunae (Decapoda, Brachyura, Potamidae) reflects five million years of geological history of Taiwan. Journal of Biogeography 33: 980-989.

Shih HT, Yeo DCJ, Ng PKL. 2010. The collision of the Indian plate with Asia: molecular evidence for its impact on the phylogeny of freshwater crabs (Brachyura: Potamidae). Journal of Biogeography 36: 703-719.

Tamura K, Stecher G, Peterson D, Filipski A, Kumar S. 2013. MEGA 6: Molecular evolutionary genetics analysis version 6.0. Molecular Biology and Evolution 30: 27252729.

Trifinopoulos J, Nguyen LT, Haeseler AV, Minh BQ. 2016. W-IQ-TREE: a fast online phylogenetic tool for maximum likelihood analysis. Nucleic Acids Research 44: W232W235.

Türkay M, Dai AY. 1997. Review of the Chinese freshwater crabs previously placed in the genus Malayopotamon Bott, 1968 (Crustacea: Decapoda: Brachyura: Potamidae). The Raffles bulletin of zoology 45: 189-207.

Wang CL. 1998. Formation of Luxiao Mountains and development of its Danxia land feature. Journal of Xiangtan Normal University [in Chinese with English summary].

Yeo DCJ, Ng PKL, Cumberlidge N, Magalhães C, Daniels SR, Campos MR. 2008. Global diversity of crabs (Crustacea: Decapoda: Brachyura) in freshwater. Hydrobiologia 595: 275-286. 
490 Yeo DCJ, Shih HT, Meier R, Ng PKL. 2007. Phylogeny and biogeography of the freshwater

491

492

493

494

495

496

497

498

499

500 crab genus Johora (Crustacea: Brachyura: Potamidae) from the Malay Peninsula, and the origins of its insular fauna. Zoologica Scripta 36: 255-269.

Yi MC. 1996. Cenozoic para-orogenic movement in China. Acta Geosicientia Sinica 17: 249255 [in Chinese with English summary].

Zhou XM, Li WX. 2000. Origin of late Mesozoic igneous rocks in Southeastern China: implications for lithosphere subduction and underplating of mafic magmas. Tectonophysics 326: 269-287.

Zhou XM, Zhu CC, Naruse T. 2008. Bottapotamon nanan, a new species of freshwater crab (Decapoda, Brachyura, Potamidae) from Fujian Province, China. Crustaceana 81: 13891396. 


\section{Table 1 (on next page)}

Specimens and GenBank accession numbers of genus Bottapotamon. 


\begin{tabular}{|c|c|c|c|c|c|c|}
\hline & Localities & $\begin{array}{c}\text { Museum } \\
\text { catalogue No. }\end{array}$ & Haplotypes & $\begin{array}{l}\text { COI } \\
\text { Accession } \\
\text { No. }\end{array}$ & $\begin{array}{l}16 S \\
\text { Accession } \\
\text { No. }\end{array}$ & $\begin{array}{l}\text { H3 } \\
\text { Accession } \\
\text { No. }\end{array}$ \\
\hline \multirow{2}{*}{$\begin{array}{l}\text { Bottapotamon } \\
\text { fukiense }\end{array}$} & $\begin{array}{c}\text { Shangshan Village, } \\
\text { Zhenghe County, Fujian }\end{array}$ & NCU MCP4156 & $\mathrm{Bfj} 1$ & MK920086 & MK795653 & MK952581 \\
\hline & $\begin{array}{c}\text { Siqian Village, Shouning } \\
\text { County, Fujian }\end{array}$ & NCU MCP4090 & $\mathrm{Bfj} 2$ & MK920087 & MK795654 & MK952582 \\
\hline \multirow{5}{*}{$\begin{array}{l}\text { Bottapotamon } \\
\text { youxiense }\end{array}$} & Xiapu Village, Ningde & NCU MCP4089 & $\mathrm{Bfj} 3$ & MK920088 & MK795655 & MK952583 \\
\hline & County, Fujian & NCU MCP4089 & $\mathrm{Bfj} 4$ & MK920089 & MK795656 & MK952584 \\
\hline & Xiwei Village, Youxi & NCU MCP4092 & Byx 1 & MK920099 & MK795666 & MK952594 \\
\hline & County, Fujian & & & & & \\
\hline & $\begin{array}{l}\text { Xiwei Village, Youxi } \\
\text { County, Fujian }\end{array}$ & NCU MCP4158 & Byx 2 & MK920100 & MK795667 & MK952595 \\
\hline \multirow{4}{*}{ Bottapotamon } & $\begin{array}{l}\text { Xiwei Village, Youxi } \\
\text { County, Fujian }\end{array}$ & NCU MCP4159 & Вух3 & MK920101 & MK795668 & MK952596 \\
\hline & $\begin{array}{c}\text { Chimu Village, Youxi } \\
\text { County, Fujian }\end{array}$ & NCU MCP4091 & Bes1 & MK920081 & MK795648 & MK952576 \\
\hline & Tangsan Village, Youxi & NCU MCP4157 & Bes2 & MK920082 & MK795649 & MK952577 \\
\hline & County, Fujian & NCU MCP4157 & Bes3 & MK920083 & MK795650 & MK952578 \\
\hline
\end{tabular}




\begin{tabular}{|c|c|c|c|c|c|c|}
\hline \multirow[t]{4}{*}{ engelhardti } & & NCU MCP4157 & Bes4 & MK920084 & MK795651 & MK952579 \\
\hline & & NCU MCP4157 & Bes5 & MK920085 & MK795652 & MK952580 \\
\hline & Siqian Village, Shouning & NCU MCP4090 & Bnal & MK920093 & MK795660 & MK952588 \\
\hline & County, Fujian & NCU MCP4090 & Bna2 & MK920094 & MK795661 & MK952589 \\
\hline Bottapotamon & Yongjia County, Zhejiang & NCU MCP4038 & Bna3 & MK920095 & MK795662 & MK952590 \\
\hline \multirow[t]{3}{*}{ nanan } & & NCU MCP4038 & Bna4 & MK920096 & MK795663 & MK952591 \\
\hline & Yongjia County, Zhejiang & NCU MCP4039 & Bna5 & MK920097 & MK795664 & MK952592 \\
\hline & & NCU MCP4039 & Bna6 & MK920098 & MK79566 & MK952593 \\
\hline \multirow{4}{*}{$\begin{array}{l}\text { Bottapotamon } \\
\text { lingchuanense }\end{array}$} & Bindong Village, Lingchuan & NCU MCP3281 & Blc1 & MK920090 & MK795657 & MK952585 \\
\hline & $\begin{array}{c}\text { County, Guangxi Zhuang } \\
\text { Autonomous Region }\end{array}$ & & & & & \\
\hline & Yuanpu Village, Gongcheng & NCU MCP4076 & Blc2 & MK920091 & MK795658 & MK952586 \\
\hline & $\begin{array}{c}\text { County, Guangxi Zhuang } \\
\text { Autonomous Region }\end{array}$ & NCU MCP4076 & Blc3 & MK920092 & MK795659 & MK952587 \\
\hline \multirow{2}{*}{$\begin{array}{l}\text { Bottapotamon } \\
\text { chenzouense } \\
\text { sp.n. }\end{array}$} & Zixing County, Chenzhou & NCU MCP643 & Bczl & MK920079 & MK795646 & MK952574 \\
\hline & City, Hunan & NCU MCP643 & $\mathrm{Bcz} 2$ & MK920080 & MK795647 & MK952575 \\
\hline
\end{tabular}




\begin{tabular}{|c|c|c|c|c|c|c|}
\hline \multirow{3}{*}{$\begin{array}{l}\text { Bottapotamon } \\
\text { luxiense sp.n. }\end{array}$} & Yixiantian Wugongshan & NCU MCP4200 & Blx1 & MK993542 & MK981408 & MK993544 \\
\hline & $\begin{array}{l}\text { Mountain, Luxi County, } \\
\text { Pingxiang City, Jiangxi }\end{array}$ & & & & & \\
\hline & & NCU MCP4200 & $\mathrm{B} 1 \mathrm{x} 2$ & MK993543 & MK981409 & MK993545 \\
\hline
\end{tabular}


Table 2 (on next page)

Primer sequences used in this study. 


\begin{tabular}{|c|c|c|c|c|}
\hline Gene & $\begin{array}{l}\text { Primer } \\
\text { name }\end{array}$ & Sequence $\left(5^{\prime}-3^{\prime}\right)$ & sequence length & Reference \\
\hline \multirow{3}{*}{$\mathrm{COI}$} & COI-1490 & GGTCAACAAATCATAAAGATATTGG & \multirow{3}{*}{$750 \mathrm{bp}$} & \multirow{3}{*}{ Folmer et al., 1994} \\
\hline & & & & \\
\hline & COI-2198 & TAAACTTCAGGGTGACCA AAAAATCA & & \\
\hline \multirow{2}{*}{$\begin{array}{l}16 \mathrm{~S} \\
\text { rRNA }\end{array}$} & $16 \mathrm{~S}-1471$ & CCTGTTTANCAAAAACAT & \multirow[b]{2}{*}{$550 \mathrm{bp}$} & \multirow[b]{2}{*}{ Crandall et al., 1996} \\
\hline & $16 \mathrm{~S}-1472$ & AGATAGAAACCAACCTGG & & \\
\hline \multirow{3}{*}{ H3 } & $\mathrm{H} 3-\mathrm{F}$ & ATGGCTCGTACCAAGCAGACVGC & \multirow{3}{*}{$374 b p$} & \multirow{3}{*}{ Colgan et al., 1998} \\
\hline & & & & \\
\hline & H3-R & ATATCCTTRGGCATRATRGTGAC & & \\
\hline
\end{tabular}




\section{Table 3 (on next page)}

Morphological differences between the eight Bottapotamon species. 


\begin{tabular}{|c|c|c|c|c|c|c|c|c|}
\hline Species & B. fukiense & $\begin{array}{l}\text { B. } \\
\text { yonganense }\end{array}$ & $\begin{array}{l}\text { B. } \\
\text { engelhardti }\end{array}$ & B. nanan & $\begin{array}{l}\text { B. } \\
\text { youxiense }\end{array}$ & $\begin{array}{l}\text { B. } \\
\text { lingchuane } \\
\text { nse }\end{array}$ & $\begin{array}{l}\text { B. } \\
\text { chenzhouen } \\
\text { se sp. n }\end{array}$ & $\begin{array}{l}\text { B. luxiense } \\
\text { sp. n. }\end{array}$ \\
\hline Carapace & $\begin{array}{l}\text { Flat, } \\
\text { cervical } \\
\text { groove } \\
\text { indistinct }\end{array}$ & $\begin{array}{l}\text { Swollen,cer } \\
\text { vical groove } \\
\text { distinct }\end{array}$ & $\begin{array}{l}\text { Swollen,cer } \\
\text { vical groove } \\
\text { indistinct }\end{array}$ & $\begin{array}{l}\text { Swollen, } \\
\text { cervical } \\
\text { groove } \\
\text { distinct. }\end{array}$ & $\begin{array}{l}\text { Swollen, } \\
\text { cervical } \\
\text { groove } \\
\text { indistinct }\end{array}$ & $\begin{array}{l}\text { Swollen, } \\
\text { cervical } \\
\text { groove } \\
\text { indistinct }\end{array}$ & $\begin{array}{l}\text { Swollen, } \\
\text { cervical } \\
\text { groove } \\
\text { indistinct }\end{array}$ & $\begin{array}{l}\text { Swollen, } \\
\text { cervical } \\
\text { groove } \\
\text { distinct. }\end{array}$ \\
\hline $\begin{array}{c}\text { External } \\
\text { orbital } \\
\text { angle }\end{array}$ & Blunt & Triangle & Blunt & Blunt & Triangle & Triangle & Triangle & Triangle \\
\hline $\begin{array}{c}\text { Third } \\
\text { maxilliped } \\
\text { merus }\end{array}$ & $\begin{array}{l}\text { Length to } \\
\text { width ratio } \\
1.3\end{array}$ & $\begin{array}{l}\text { Length to } \\
\text { width ratio } \\
1.1\end{array}$ & $\begin{array}{l}\text { Length to } \\
\text { width ratio } \\
1.2\end{array}$ & $\begin{array}{l}\text { Length to } \\
\text { width ratio } \\
1.4\end{array}$ & $\begin{array}{l}\text { Length to } \\
\text { width ratio } \\
1.1\end{array}$ & $\begin{array}{l}\text { Length to } \\
\text { width ratio } \\
1.2\end{array}$ & $\begin{array}{l}\text { Length to } \\
\text { width ratio } \\
1.3\end{array}$ & $\begin{array}{l}\text { Length to } \\
\text { width ratio } \\
1.4\end{array}$ \\
\hline $\begin{array}{c}\text { Male } \\
\text { abdomen }\end{array}$ & $\begin{array}{l}\text { Broad } \\
\text { triangular }\end{array}$ & $\begin{array}{l}\text { Narrow } \\
\text { triangular }\end{array}$ & $\begin{array}{l}\text { Broad } \\
\text { triangular }\end{array}$ & $\begin{array}{l}\text { Broad } \\
\text { triangular }\end{array}$ & $\begin{array}{l}\text { Broad } \\
\text { triangular }\end{array}$ & $\begin{array}{l}\text { Broad } \\
\text { triangular }\end{array}$ & $\begin{array}{l}\text { Narrow } \\
\text { Triangular }\end{array}$ & $\begin{array}{l}\text { Broad } \\
\text { triangular }\end{array}$ \\
\hline $\begin{array}{c}\text { Male } \\
\text { abdomen } \\
\text { telson }\end{array}$ & $\begin{array}{l}\text { Width to } \\
\text { length ratio } \\
1.5\end{array}$ & $\begin{array}{l}\text { Width to } \\
\text { length ratio } \\
1.3\end{array}$ & $\begin{array}{l}\text { Width to } \\
\text { length ratio } \\
1.3\end{array}$ & $\begin{array}{l}\text { Width to } \\
\text { length ratio } \\
1.4\end{array}$ & $\begin{array}{l}\text { Width to } \\
\text { length ratio } \\
1.5\end{array}$ & $\begin{array}{l}\text { Width to } \\
\text { length ratio } \\
1.2\end{array}$ & $\begin{array}{l}\text { Width to } \\
\text { length ratio } \\
1.3\end{array}$ & $\begin{array}{l}\text { Width to } \\
\text { length ratio } \\
1.3\end{array}$ \\
\hline $\begin{array}{c}\text { Immovable } \\
\text { finger }\end{array}$ & $\begin{array}{l}\text { Length to } \\
\text { width ratio } \\
1.3\end{array}$ & $\begin{array}{l}\text { Length to } \\
\text { width ratio } \\
1.7\end{array}$ & $\begin{array}{l}\text { Length to } \\
\text { width ratio } \\
1.4\end{array}$ & $\begin{array}{l}\text { Length to } \\
\text { width ratio } \\
1.7\end{array}$ & $\begin{array}{l}\text { Length to } \\
\text { width ratio } \\
1.7\end{array}$ & $\begin{array}{l}\text { Length to } \\
\text { width ratio } \\
1.4\end{array}$ & $\begin{array}{l}\text { Length to } \\
\text { width ratio } \\
1.4\end{array}$ & $\begin{array}{l}\text { Length to } \\
\text { width ratio } \\
1.8\end{array}$ \\
\hline G1 & $\begin{array}{l}\text { Stout, } \\
\text { straight }\end{array}$ & $\begin{array}{l}\text { Slender, } \\
\text { distal } \\
\text { segment } \\
\text { tabular }\end{array}$ & $\begin{array}{l}\text { Slender, } \\
\text { distal dorsal } \\
\text { lobe convex }\end{array}$ & $\begin{array}{l}\text { Slender, } \\
\text { distinct } \\
\text { longitudinal }\end{array}$ & $\begin{array}{l}\text { Slender, } \\
\text { distal } \\
\text { segment } \\
\text { spacious }\end{array}$ & $\begin{array}{l}\text { Slender, } \\
\text { terminal, } \\
\text { segment } \\
\text { tortuous }\end{array}$ & $\begin{array}{l}\text { Slender, } \\
\text { ventral flap } \\
\text { with } \\
\text { transparent }\end{array}$ & Blunt \\
\hline
\end{tabular}


protrusion 
Figure 1

Collection sites for the genus Bottapotamon.

The regional map comes from https://commons.wikimedia.org/wiki/Atlas_of the world and http://landsatlook.usgs.gov/; the map was edited with Adobe Photoshop CS6.

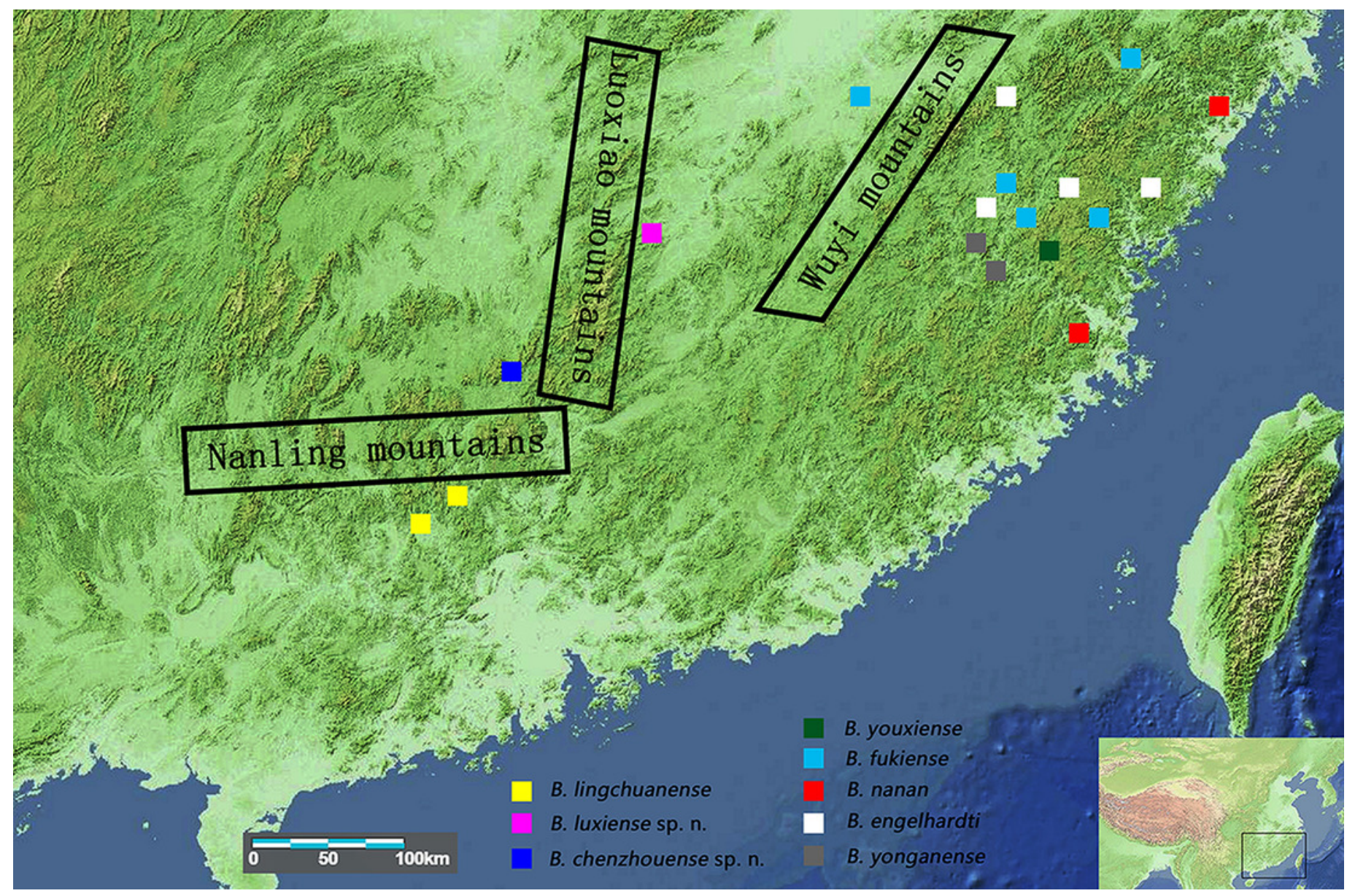




\section{Figure 2}

Bottapotamon chenzhouense sp. n. Holotype male $(20.67 \times 15.60 \mathrm{~mm})($ NCU MCP 643$)$.

(A) Overall habitus; (B) frontal view of cephalothorax. Photograph taken by Jie-Xin Zou, November 2018.

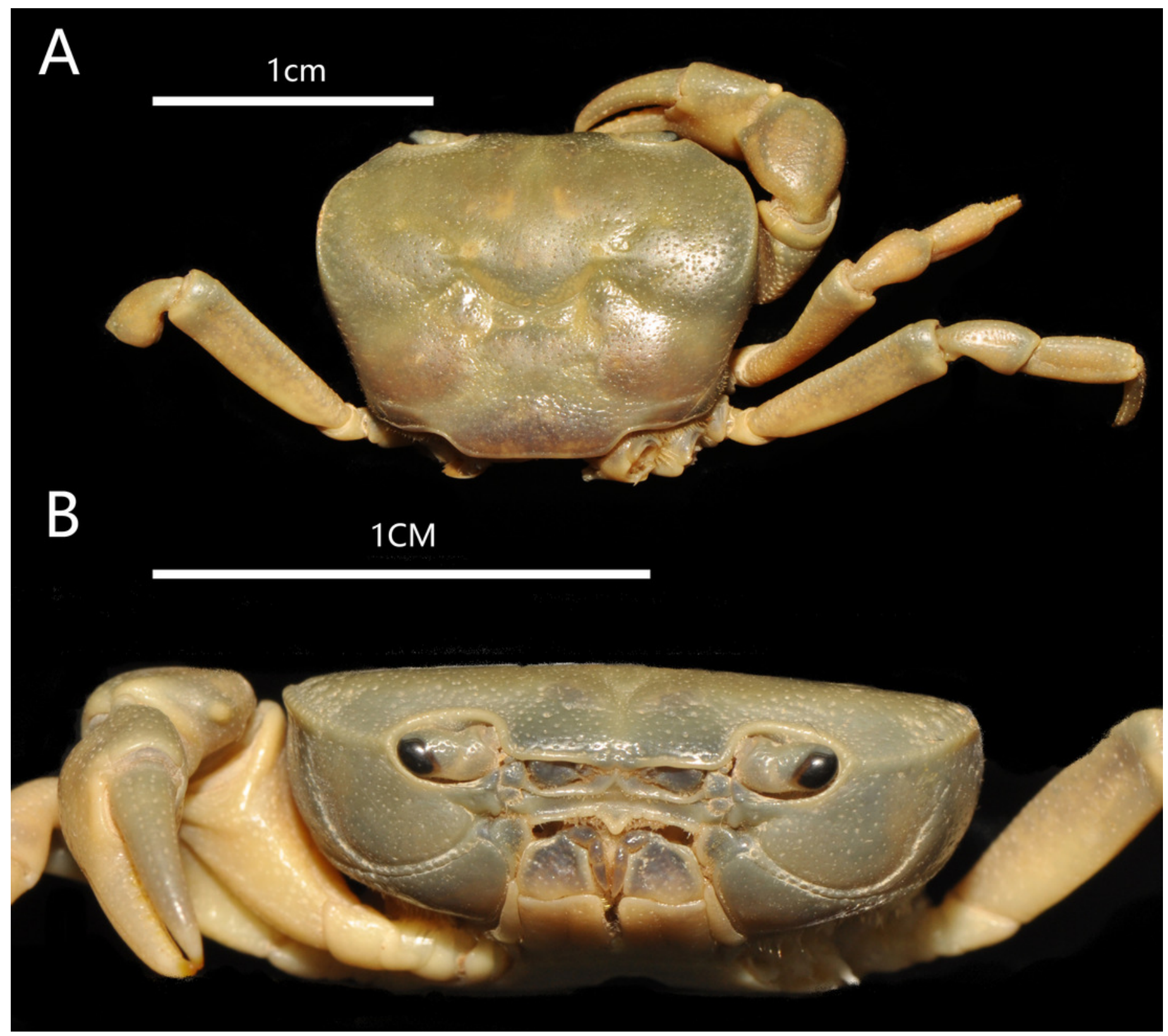




\section{Figure 3}

Bottapotamon chenzhouense sp. n. Holotype male $(20.67 \times 15.60 \mathrm{~mm})($ NCU MCP 643).

(A) left third maxilliped; (B) right fourth ambulatory leg; (C) outer view of chelipeds.

Photograph taken by Jie-Xin Zou, November 2018.

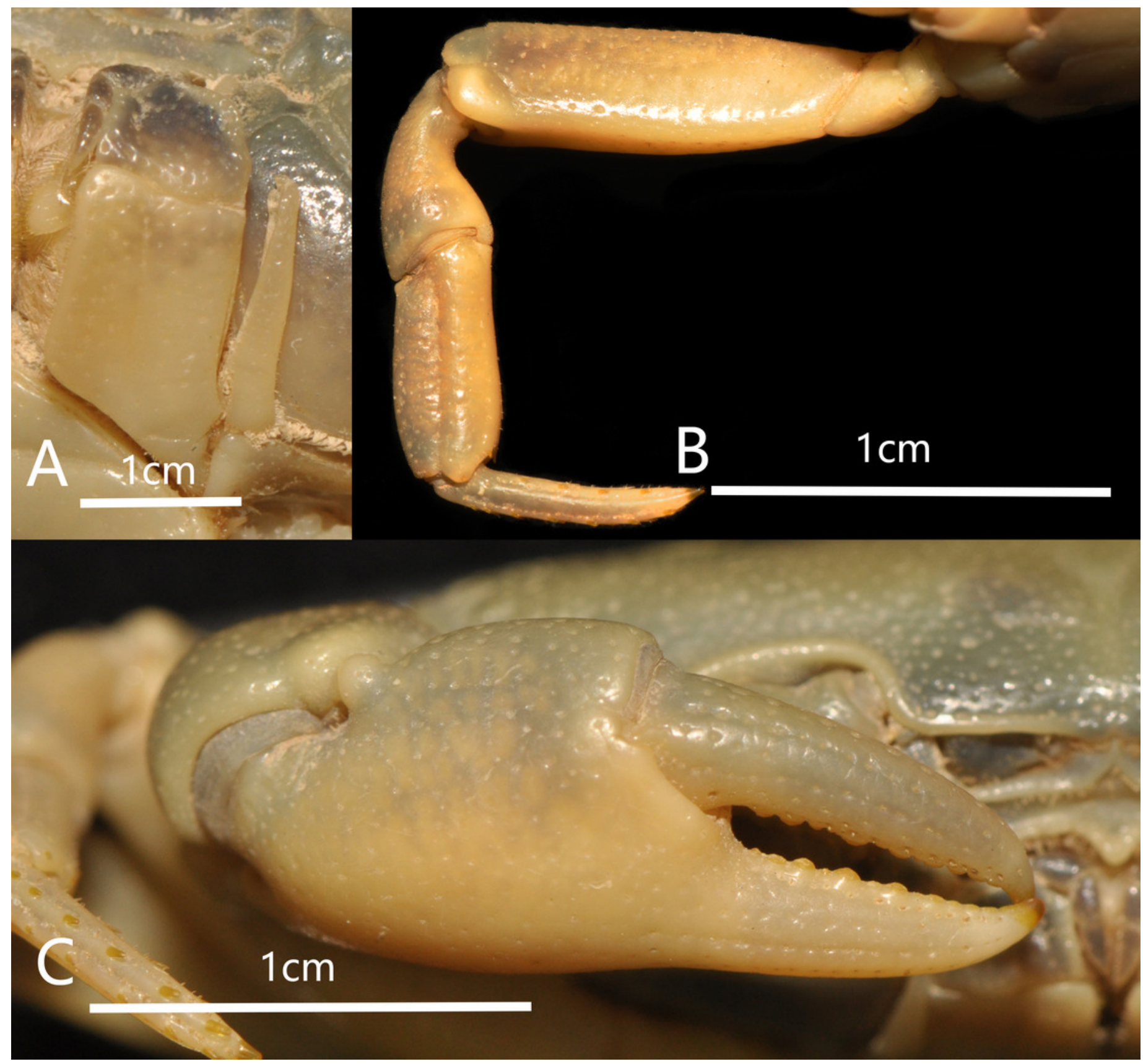


Figure 4

Bottapotamon chenzhouense sp. n. Holotype male $(20.67 \times 15.60 \mathrm{~mm})($ NCU MCP 643).

(A) male sternum. Interruption between sutures of sternites 4/5, 5/6, 6/7; tubercle of abdominal lock. (B) median logitudinal suture of sternites7, 8. Photograph taken by Jie-Xin Zou, November 2018. 


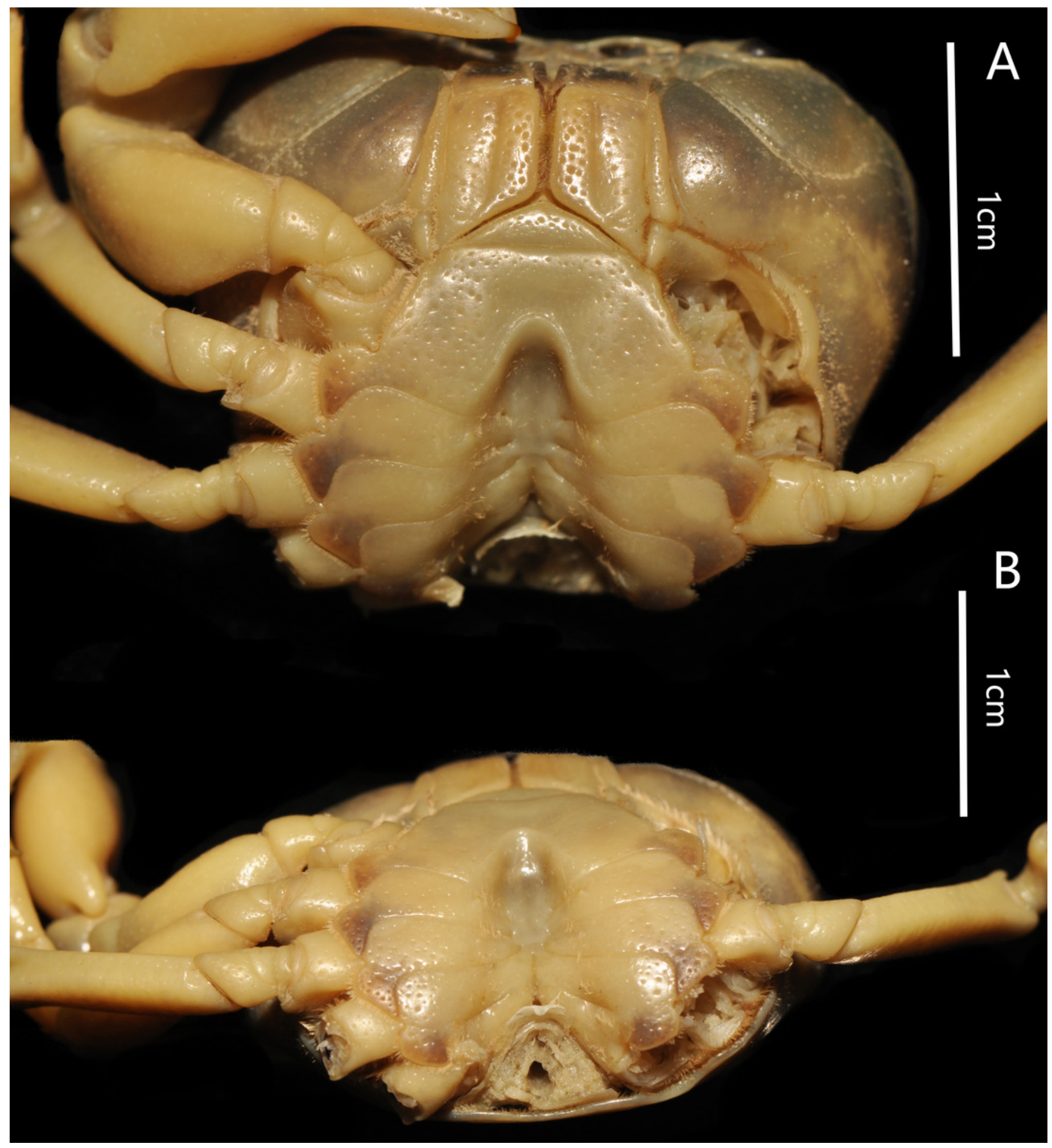


Figure 5

Gonopods (A-I).

(A-D) Bottapotamon chenzhouense sp .n. Holotype male (20.67 × $15.60 \mathrm{~mm}$ ) (NCU MCP 643);

(E-I) Bottapotamon luxiense sp. n. Holotype male ( 17.36 x 13.26 mm ) ( NCU MCP 4200). 

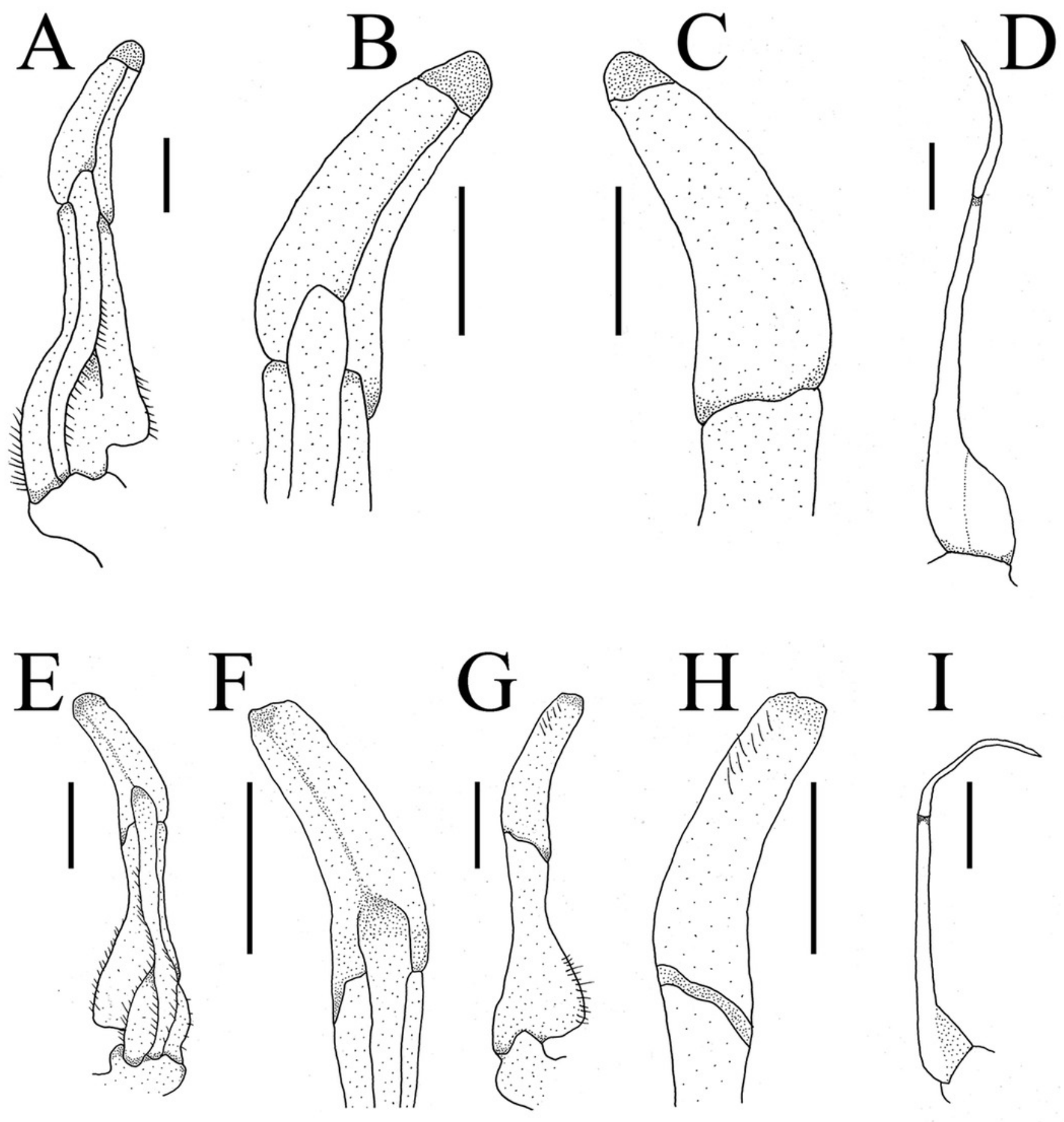
Figure 6

Natural position of male G1 and median longitudinal suture of sternites 7,8 .

(A) Bottapotamon chenzhouense sp. n. Holotype male (20.67 × $15.60 \mathrm{~mm}$ ) (NCU MCP 643);

(B) Bottapotamon luxiense sp. n. Holotype male ( 17.36 x 13.26 mm) ( NCU MCP 4200).

Photograph taken by Jie-Xin Zou, November 2018. 


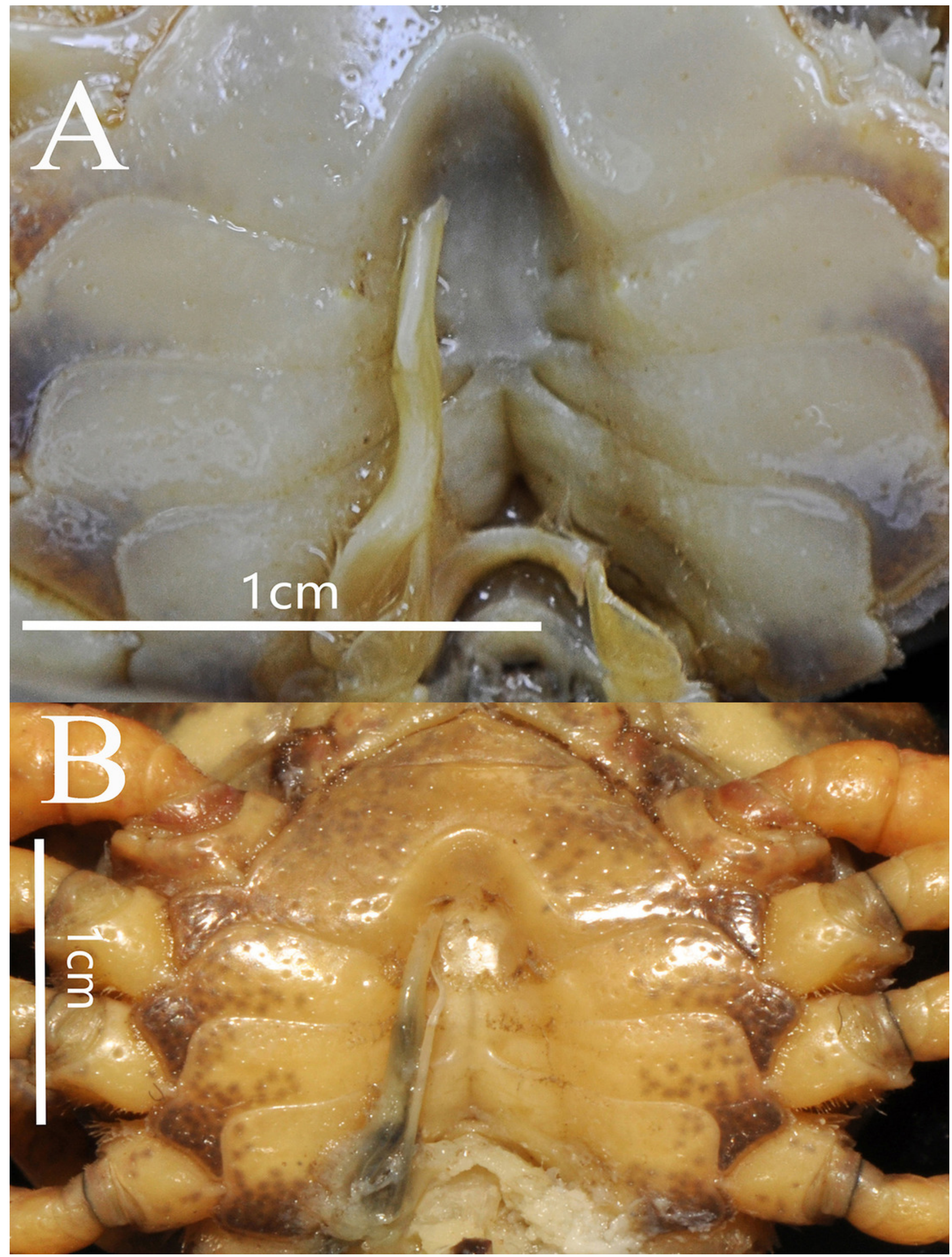




\section{Figure 7}

Bottapotamon luxiense sp. $\mathrm{n}$. Holotype male (17.36 x 13.26 mm) ( NCU MCP 4200-Blx1 ).

Overall habitus. Photograph taken by Jie-Xin Zou, May 2019.

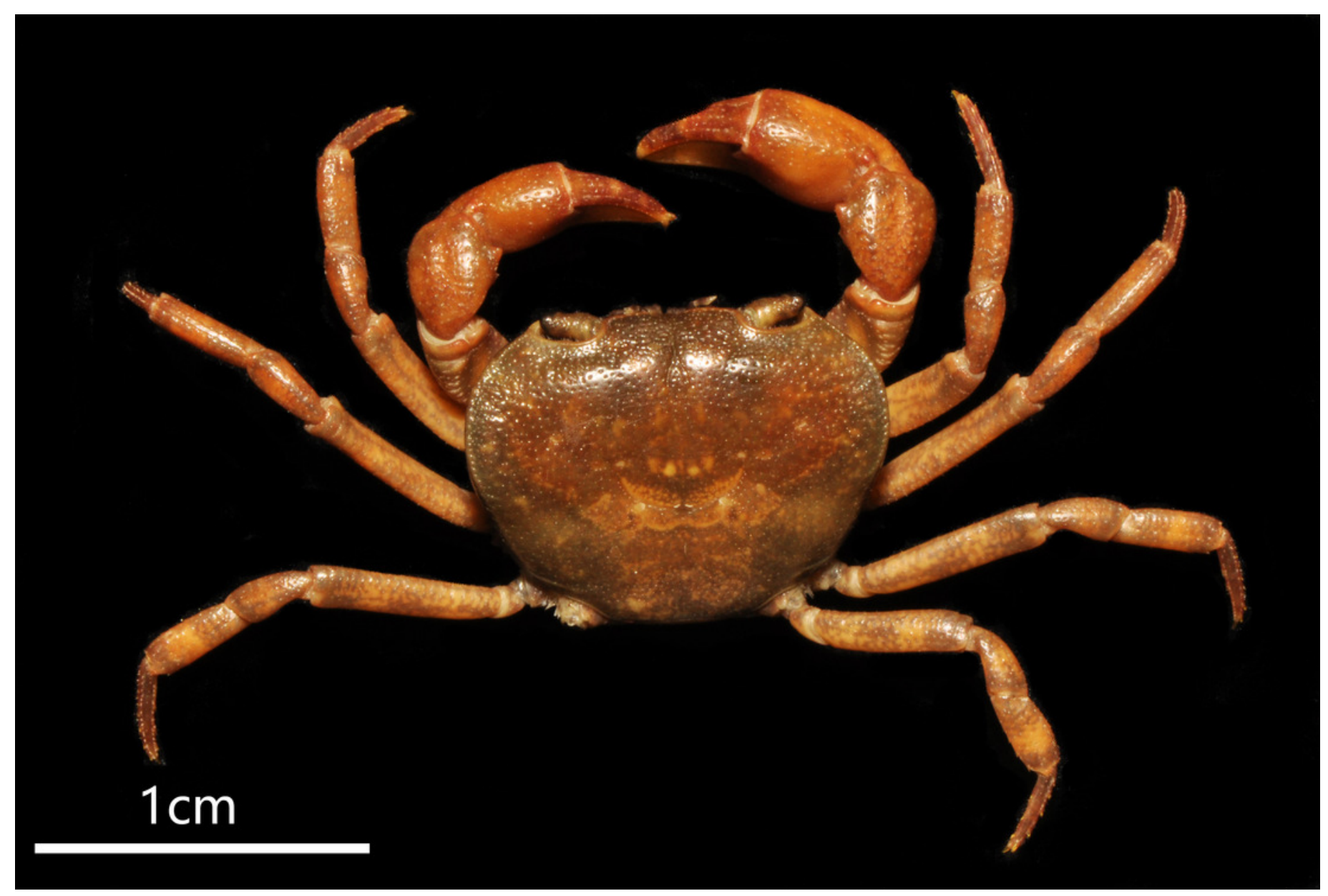




\section{Figure 8}

Bottapotamon luxiense sp. n. Holotype male ( $17.36 \times 13.26$ mm ) ( NCU MCP 4200).

(A) left third maxilliped; (B) outer view of chelipeds; (C) right fourth ambulatory leg.

Photograph taken by Jie-Xin Zou, May 2019.

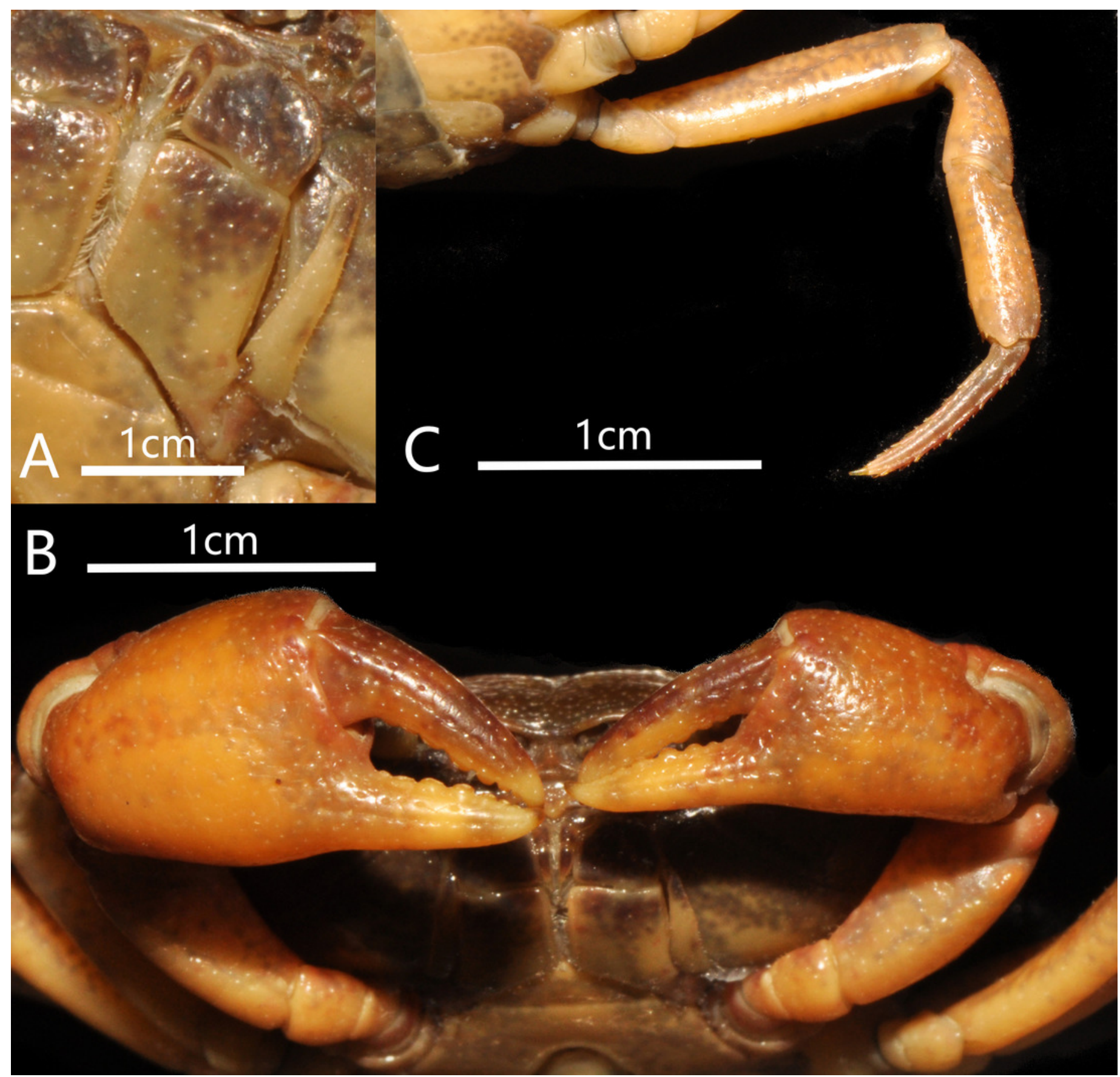


Figure 9

Bottapotamon luxiense sp. n. Holotype male ( 17.36 x 13.26 mm ) ( NCU MCP 4200-Blx1 ).

Male sternum. Photograph taken by Jie-Xin Zou, May 2019.

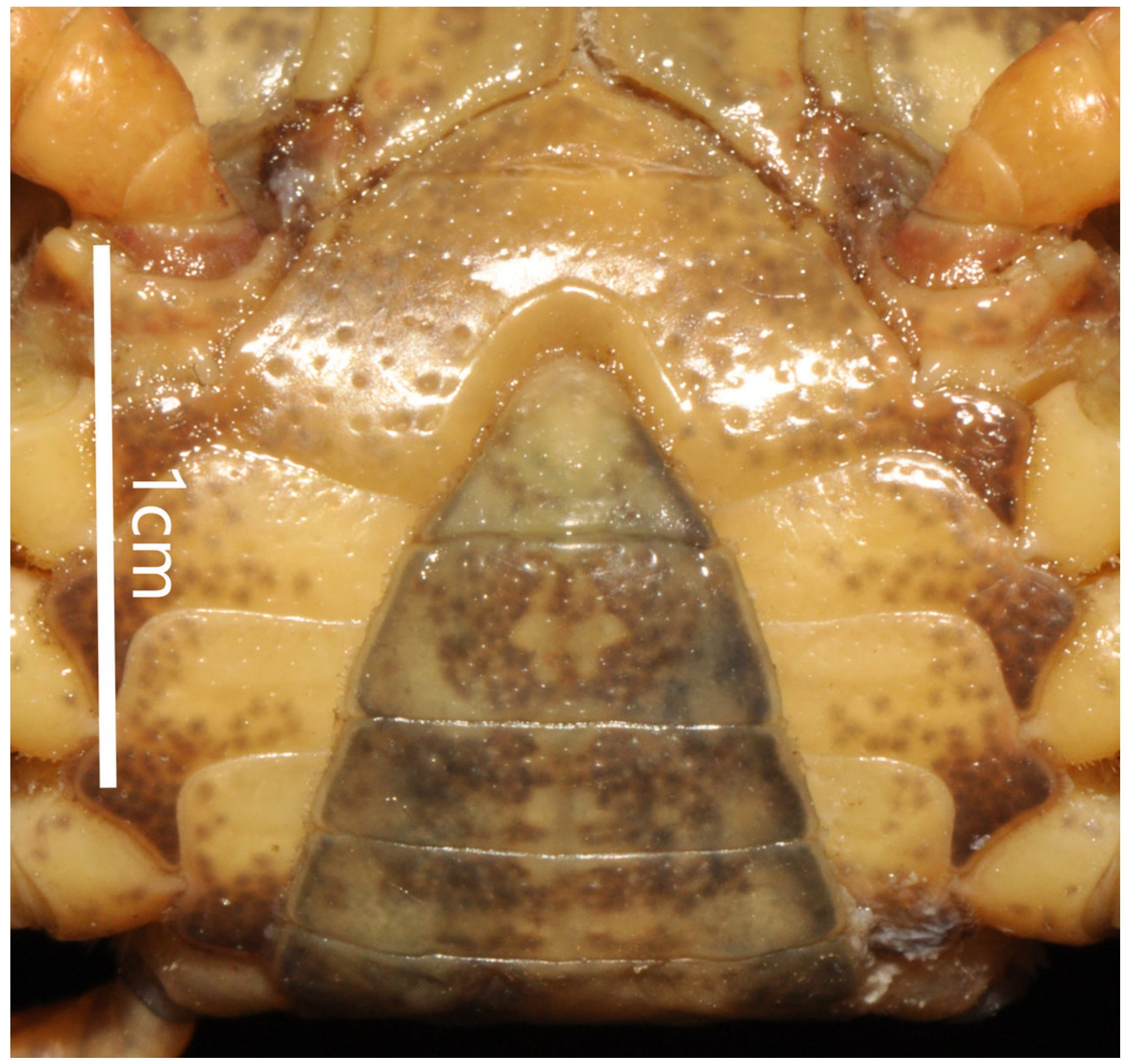




\section{Figure 10}

The type locality of Bottapotamon Iuxiense sp. $\mathrm{n}$.

(A) Living under rocks. (B) Surroundings of type locality. Photo taken by Song-bo Wang, May 2019
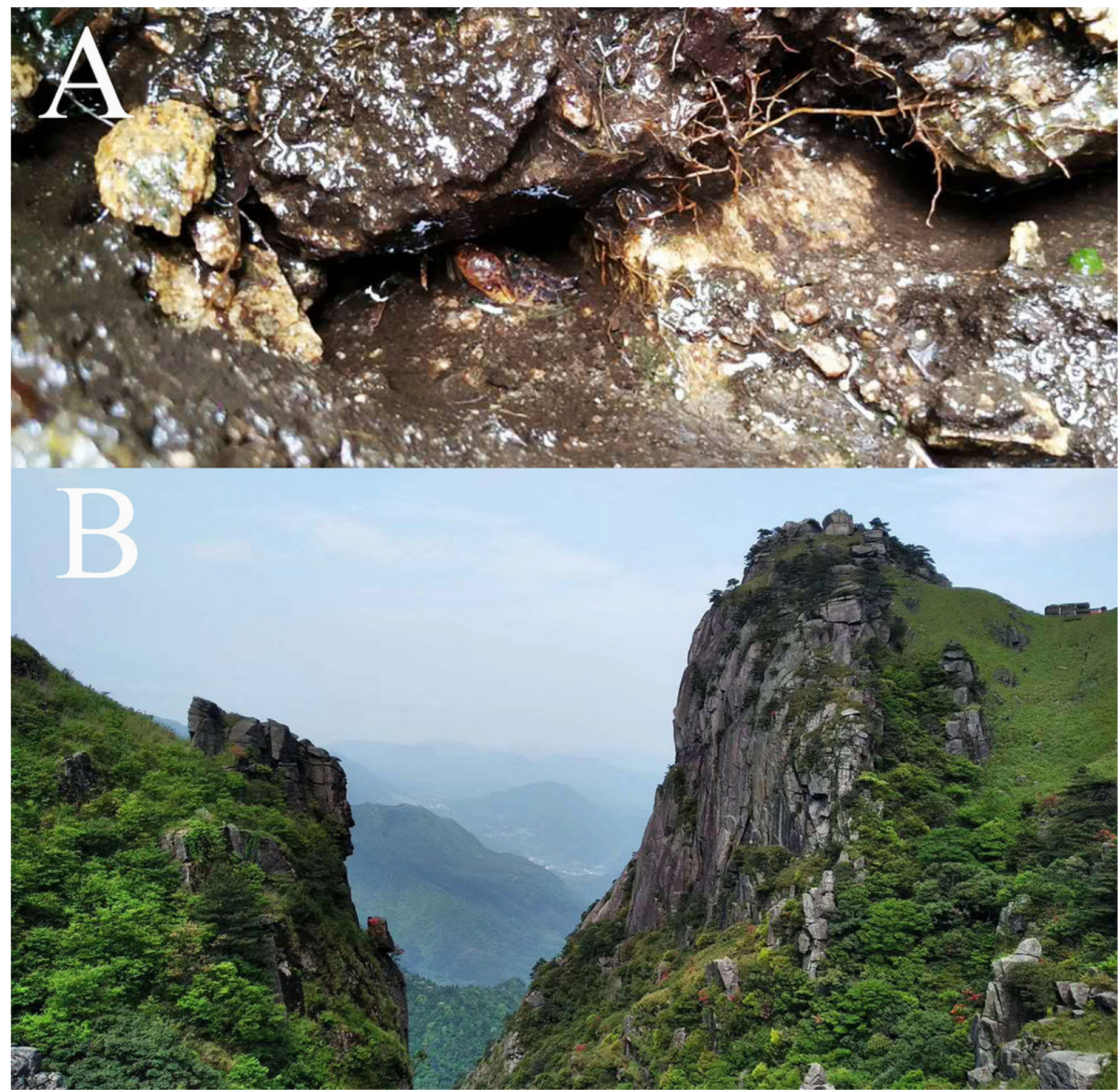


\section{Figure 11}

Phylogenetic tree of the genus Bottapotamon.

A maximum likelihood (ML) tree of the genus Bottapotamon, and outgroups, based on the combined mtDNA COI, 16S rRNA and nuclear histone H3 genes (length=1404bp). Support values $(\mathrm{P} \geqq 50 \%)$ for $\mathrm{ML}, \mathrm{BI}$ is represented at the nodes. Locality names in Table 1 are parenthesized behind specimens.

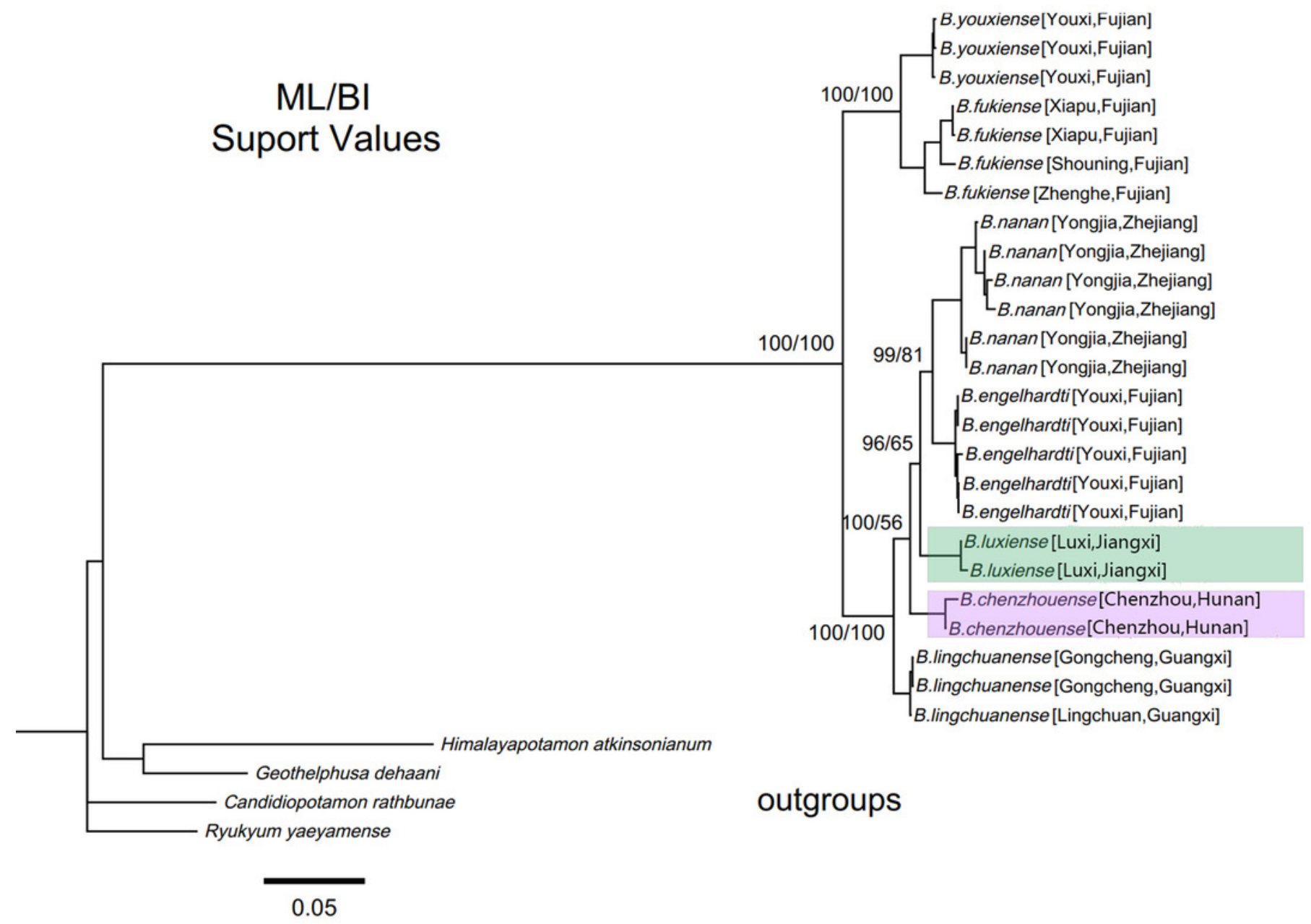


Figure 12

A chronogram of the genus Bottapotamon.

Based on the mtDNA COI, 16S rRNA genes. The divergence times for genus Bottapotamon and Calibration points are shown at the main nodes. Calibration point 1 was set for the divergence time between subfamily Potamiscinae and subfamily Potaminae (estimated value $=21.50 \mathrm{Ma}$ ); Calibration point 2 was set for the glacial periods in Taiwan Strait (

Somanniathelphusa taiwanensis and Somanniathelphusa amoyensis, estimated value $=0.40$ Ma); Formation time of Wuyi mountains was set for Calibration point 3 (The divergence time of $B$. fukiense is $1.96 \mathrm{Ma})$.

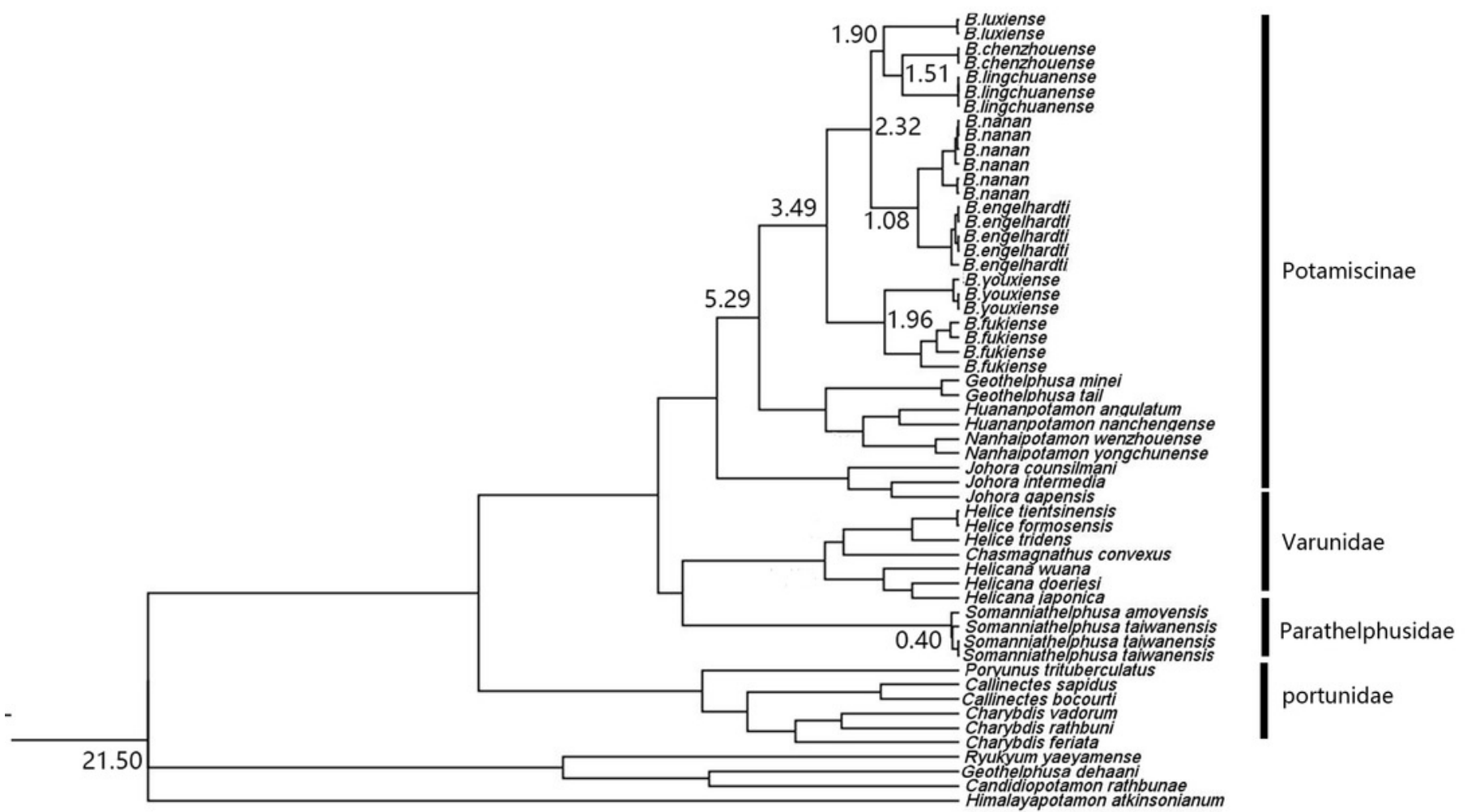

3.0 